\title{
Beyond Lipid Signaling: Pleiotropic Effects of Diacylglycerol Kinases in Cellular Signaling
}

\author{
Jae Ang Sim ${ }^{1}$, Jaehong Kim ${ }^{2} \odot$ and Dongki Yang ${ }^{3, *}$ \\ 1 Department of Orthopedic Surgery, Gil Medical Center, College of Medicine, Gachon University, \\ Incheon 21565, Korea; sim_ja@gilhospital.com \\ 2 Department of Biochemistry, College of Medicine, Gachon University, Incheon 21999, Korea; \\ geretics@gachon.ac.kr \\ 3 Department of Physiology, College of Medicine, Gachon University, Incheon 21999, Korea \\ * Correspondence: dkyang@gachon.ac.kr; Tel.: +82-32-899-6072
}

Received: 26 August 2020; Accepted: 16 September 2020; Published: 18 September 2020

\begin{abstract}
The diacylglycerol kinase family, which can attenuate diacylglycerol signaling and activate phosphatidic acid signaling, regulates various signaling transductions in the mammalian cells. Studies on the regulation of diacylglycerol and phosphatidic acid levels by various enzymes, the identification and characterization of various diacylglycerol and phosphatidic acid-regulated proteins, and the overlap of different diacylglycerol and phosphatidic acid metabolic and signaling processes have revealed the complex and non-redundant roles of diacylglycerol kinases in regulating multiple biochemical and biological networks. In this review article, we summarized recent progress in the complex and non-redundant roles of diacylglycerol kinases, which is expected to aid in restoring dysregulated biochemical and biological networks in various pathological conditions at the bed side.
\end{abstract}

Keywords: diacylglycerol kinase; diacylglycerol; phosphatidic acid; tissue microenvironment; tumor microenvironment; lipid signaling

\section{Introduction}

The addition or removal of phosphate group in lipids or proteins is critical for cellular signal transduction. Diacylglycerol kinases (DGKs, EC 2.7.1.107), which are involved in the phosphoinositide signaling pathway, mediate the cellular responses to abiotic and biotic stresses. In the DGK-catalyzed reaction, $\gamma$-phosphate of adenosine triphosphate (ATP) is transferred to the hydroxyl group of sn-1,2 diacylglycerol (DAG), which promotes the synthesis of phosphatidic acid (PA) from DAG (Figure 1). DGK $\alpha$ was first purified from the pig brain in 1983 [1]. The human DGK $\alpha$ cDNA was cloned from the leukocytes in 1990 [2]. In 1994, human DGK $\alpha$ was genetically mapped to chromosome 12 [3]. Currently, 10 mammalian DGK isozymes have been identified $(\alpha[2,4], \beta[5], \gamma[6,7], \delta[8], \eta[9], \kappa[10]$, $\varepsilon$ [11], $\zeta$ [12], ı [13], and $\theta$ [14]). The activity of DGK is detected in various tissues and organisms (from Escherichia coli to mammals) [15-17]. The number of DGK isoforms varies from yeast (single enzyme) to mammals (10 isozymes, some with splicing variants) and the specialized activity of DGK increases with the complexity of organisms. The phenotypes of DGK knockout (KO) mouse and the disease-associated changes in the expression and activity of DGKs indicate that DGK isoforms exhibit specialized non-redundant functions [16]. 


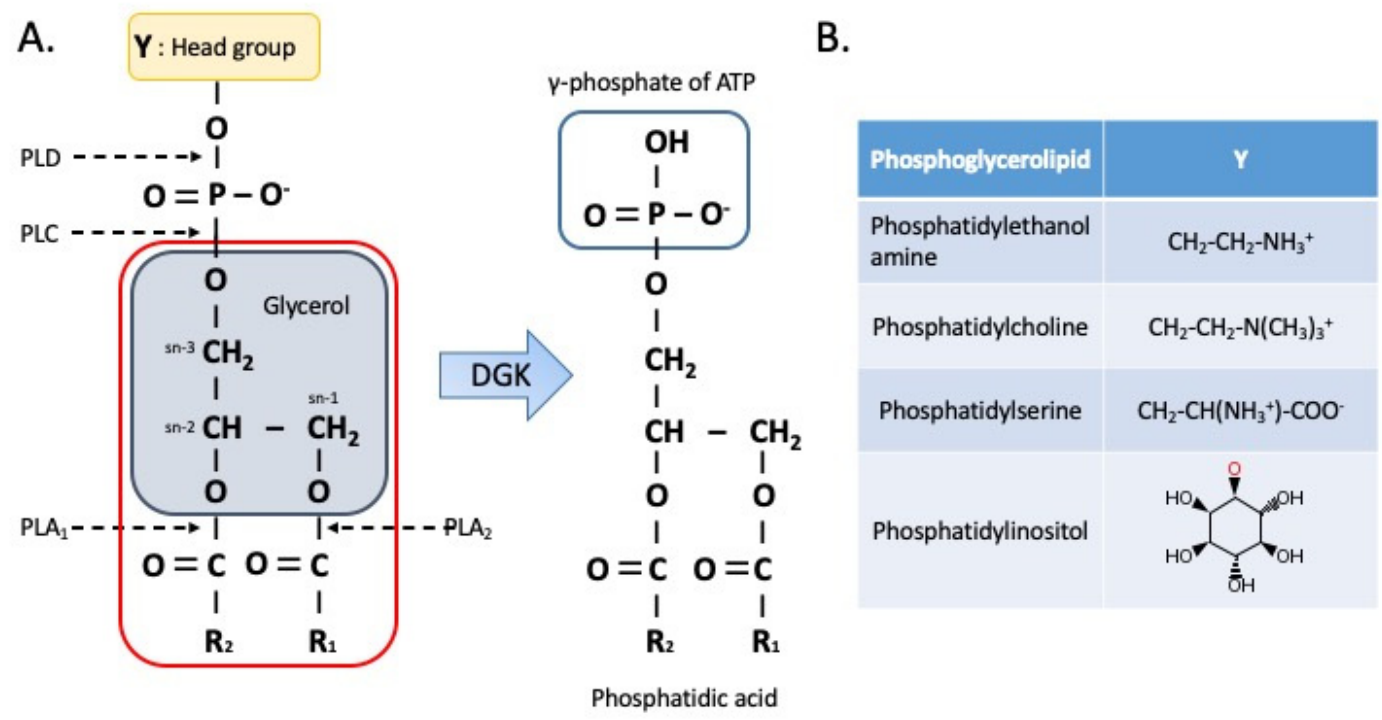

Figure 1. Structure of phosphoglycerolipid including diacylglycerol (DAG) and phosphatidic acid (PA). (A) The sites for phospholipase-mediated hydrolysis of phosphoglycerolipid are marked in letters. Structure of DAG is presented in a rounded red rectangle. (B) The head groups $(\mathrm{Y})$ of selected phosphoglycerolipid classes are presented. $\mathrm{Y}$ is ethanolamine, choline, serine and inositol from top to bottom. O in red indicates hydroxyl group of phosphoglycerolipid where the inositol residue is bound. ATP, adenosine triphosphate; DGK, diacylglycerol kinase; PLA, phospholipase A; PLC, phospholipase C; PLD, phospholipase D. $R_{1}$ and $R_{2}$ are fatty acid residues.

The structures of DGK isoforms are presented in Figure 2. The mammalian DGKs, which have at least two cysteine-rich $\mathrm{C} 1$ domains ( $\mathrm{C} 1 \mathrm{a}$ and $\mathrm{C} 1 \mathrm{~b}$ domain) for interacting with DAG and one kinase domain with catalytic and accessory subdomains, represent a large enzyme family. The ten isoforms of mammalian DGKs are grouped into five types based on the homology of their structural features $[18,19]$. Type I DGKs $(\alpha, \beta$, and $\gamma)$ sequentially contain two calcium-binding EF-hand motifs (which enable the enzymes to respond to $\left.\mathrm{Ca}^{2+}[20]\right)$, two $\mathrm{C} 1$ domains, and a catalytic domain. In the $\mathrm{T}$ cells, $\mathrm{Ca}^{2+}$ modulates the enzyme activity and also appears to localize DGK $\alpha$ activity [21]. Type II DGKs $(\delta, \eta$, and $\kappa$ ) have an $\mathrm{N}$-terminal pleckstrin homology $(\mathrm{PH})$ domain that interacts with phosphatidylinositol (PI), two C1 domains, two catalytic domains, and finally, a C-terminal sterile $\alpha$-motif (SAM) domain. Type III DGK $(\varepsilon)$, which is the shortest DGK isoform, contains two C1 domains, followed by a catalytic domain. Type IV DGKs ( $\zeta$ and $\iota$ ) contain two $C 1$ domains, followed by a myristoylated alanine-rich protein kinase $C$ substrate phosphorylation site-like region (MARCKS homology domain), a catalytic domain, four ankyrin repeats, and a C-terminal PDZ-binding site. Type V DGK $(\theta)$ contains a prolineand glycine-rich domain, three $\mathrm{C} 1$ domains, a central $\mathrm{PH}$ domain, and a catalytic domain. A recent phylogenetic analysis of the conserved regions in the DGK catalytic domain of the main vertebrate classes and eukaryotic phyla demonstrated the evolutionary relationships between DGKs [22].

The elucidation of the physiological roles of DGKs has been challenging. The number of DGK isoforms varies in different mammalian tissues (at least one member of the DGK is expressed in all mammalian tissues and most DGK isoforms are abundantly expressed in the brain and hematopoietic cells) [23]. The analysis of expressed sequence tag data from the National Center for Biotechnology Information database containing the tissue expression pattern of DGKs revealed that the spectrum of DGK isoform expression is relatively narrow in several tissues [24].

The catalytic domains of the DGK isoforms effectively phosphorylate DAG through a regulated process. The differences in the activity of DGK isoforms are attributed to the structural variations in other domains, which determine the interaction with proteins that regulate the activity and subcellular localization of DGK isoforms. DGKs have kinase-dependent and kinase-independent functions [25]. 


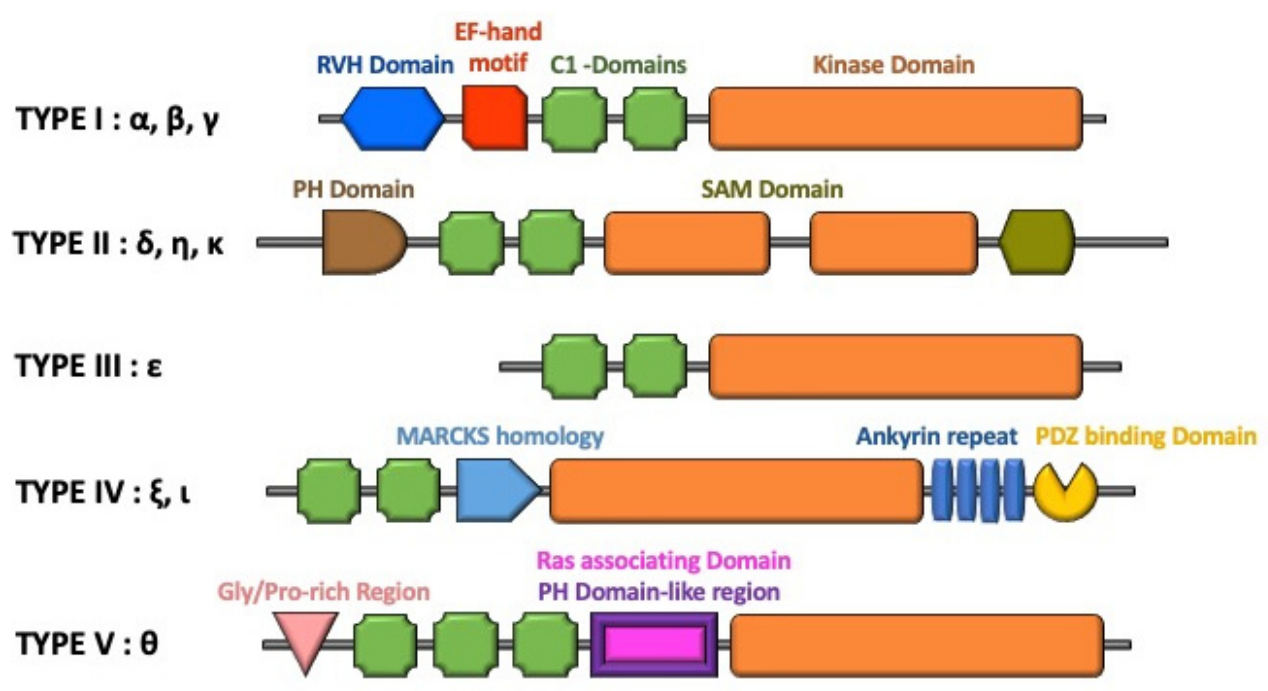

Figure 2. The structures of DGKs. DGK isoforms are classified into five types. Gly/Pro, glycine/proline; $\mathrm{PH}$, pleckstrin homology; RVH, recoverin homology domain; MARCKS, myristoylated alanine rich protein kinase $\mathrm{C}$ substrate phosphorylation site; SAM, sterile alpha motif.

At present, there is an important agenda to fulfill. The importance of different DGK isoforms (some of which share structural similarity) is unknown. These isoforms appear to exhibit non-redundant functions [26]. Thus, the evolutionary importance of DGK family enzymes with a low functional redundancy between the isoforms is not clear. It is important to identify the specific functions of different DGK isoforms localized in different subcellular compartments, such as the plasma membrane, endoplasmic reticulum (ER) and Golgi complex, cytoskeleton, endosomes, and nucleus. Additionally, the spatiotemporal regulation of DGK isoforms in the subcellular compartment must be examined. Furthermore, the therapeutic effects of DGK inhibitors on the tissue microenvironment, which comprises different types of epithelial, stromal, and immune cells, must be evaluated. Finally, DGK isoform-specific inhibitors must be identified.

\section{Regulation of DAG and PA Levels}

The DAG-dependent and PA-dependent signaling can be distinctly represented. However, both these signaling pathways are interconnected and they are essential for maintaining cellular homeostasis. Hence, this review will discuss various mechanisms that regulate the DAG and PA levels in the eukaryotic cells, especially in mammals to maintain the homeostasis of cells and organs.

DGKs are one of the pivotal enzymes in lipid signal transduction. Since DAG is primarily metabolized by DGKs to produce PA, DGKs regulate multiple signaling pathways through the attenuation of DAG signaling and initiation of PA signaling pathways. Both DAG and PA can serve as important secondary messengers [27]. In contrast to PA, DAG moves freely across the trans-bilayer membranes in a process called "flip flop" without protein assistance [28].

Representative pathways for DAG regulation are illustrated in Figure 3. The chemical structures of DAG species are highly variable and DAGs represent a class of lipid molecules exhibiting various isomeric properties. Glycerol-3-phosphate (G3P) is the basic building block of every phospholipid (PL) with a phosphate residue at the sn-3 position. Owing to the sn-3 position of the phosphate residue in PLs, DAGs generated from the hydrolysis of the PL headgroup or the dephosphorylation of PA by phosphatic acid phosphatases (PAPases, LIPINs) are per definition sn-1,2 isomers (Figures 1 and 3) $[29,30]$. The DAG pool in the plasma membrane and ER/Golgi network is reported to comprise sn-1,2 DAGs [29,30]. The selective substrate for DGKs is sn-1,2 DAGs [29], while that for DGKe is DAG with an arachidonoyl group (C20:4), which is the main product of phosphatidylinositol phospholipase C-mediated phosphoinositide hydrolysis at the sn-2 position [31]. In addition to the 
plasma membrane, DGK isoforms are involved in the DAG/PA metabolism in the nucleus, ER/Golgi complex, and cytoskeleton [24,29,32].

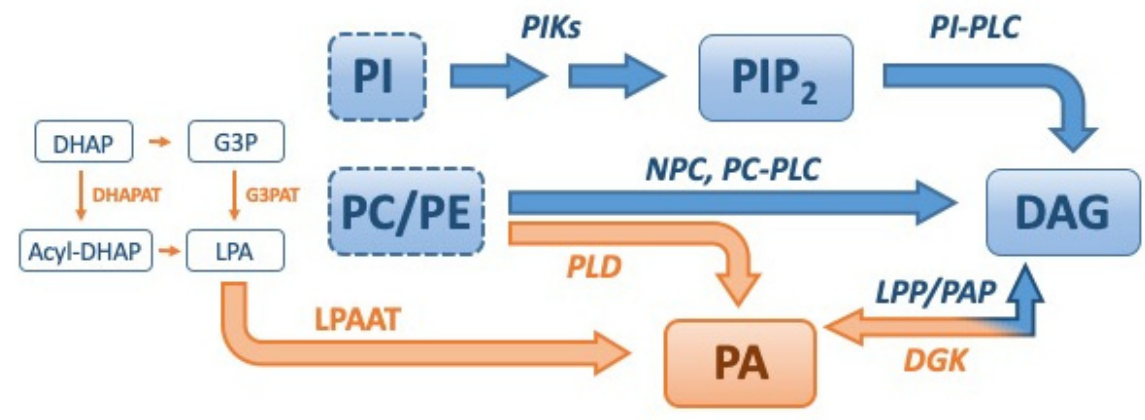

Figure 3. Representative pathways involved in the metabolism of diacylglycerol (DAG) and phosphatidic acid (PA). The biosynthetic pathways of DAG and PA are shown in blue and orange, respectively. The key enzymes of the DAG and PA biosynthetic pathway are shown in blue and orange italics, respectively. The enzyme inhibitors are represented in green font. The pathways involved in the degradation of DAG and PA are shown in black font. AT, acyltransferase; DHAP, dihydroxyacetone-3-phosphate; G3P, glycerol-3-phosphate; LPA, lysophosphatidic acid; LPAAT, LPA acyl transferase; LPP, lipid phosphate phosphatase; NPC, non-specific phospholipase C; PAP, phosphatidic acid phosphatase; PC, phosphatidylcholine; PE, phosphatidylethanolamine; PI, phosphatidylinositol; PIK, phosphatidylinositol kinase; PLC, phospholipase C; PLD, phospholipase D.

Protein kinase C (PKC) is activated by sn-1,2 DAG [18,33,34]. Additionally, PKC interacts with various protein targets, including the protein kinase D family members [23,35], Ras guanyl nucleotide-release proteins (RASGRP: exchange factors for Ras/Rap1) [34], chimaerins (a family of Rac GTPase-activating proteins) [36], Munc13 family (scaffolding proteins involved in exocytosis) [37], and some transient receptor potential canonical channels $\left(\mathrm{Ca}^{2+}\right.$-permeable nonselective cation channels) [38]. Thus, the DGK-mediated hydrolysis of DAG regulates various cellular processes. DAG can also regulate the membrane translocation and activity of its interacting proteins by binding to their $\mathrm{C} 1$ domains $[39,40]$.

PA localizes to various subcellular compartments, such as the plasma membrane, ER, Golgi complex, mitochondria, and nucleus [41], and interacts with the putative PA-binding regions, whose consensus sequence has not been characterized, of more than 50 different proteins $[42,43]$. Additionally, PA regulates various signaling proteins, including mammalian/mechanistic target

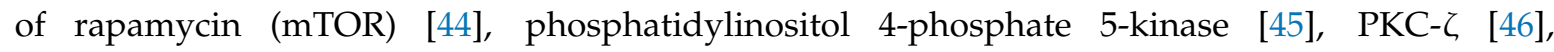
protein phosphatase 1 [47], Src homology region 2 domain-containing phosphatase 1, ArfGAP, Arf, Raf1 [48], DEP (disheveled (Dsh), Egl-10, and pleckstrin) domain of Epac1 [49], Dsh proteins [50], phospholipase C- $\gamma 1$ [51], IQGAP1, and PIP5-kinase (PIPKI $\alpha$ ) [52]. Furthermore, PA modulates cell survival and proliferation, cytoskeletal organization, and membrane and vesicle trafficking [53].

In addition to DGKs, various enzymes catalyze the biosynthesis of PA [54]. For example, de novo synthesis through the sequential acylation of G3P and lysophosphatidic acid, which is the main metabolic route catalyzed by lysophosphatidic acid acyltransferase (LPAAT) and phospholipase D (PLD)-catalyzed hydrolysis of PLs, such as phosphatidylcholine (PC) or phosphatidylethanolamine (PE) are shown in Figure 3. The detailed biochemical and biological properties of DAG and PA species are excellently presented elsewhere by Eichmann [29] and Pokotylo [43], respectively.

\section{Regulation of DGK Isoforms}

\subsection{Phospholipids}

PLs can upregulate the activity of DGK isoforms [55]. The activity of DGK $\alpha$ is upregulated by PC, PIP3, and PI(3,4)P2 [1]. DGK $\beta$ is activated by PI(4,5)P2 and phosphatidylserine (PS) [56]. The activities 
of type I DGKs are dependent on $\mathrm{Ca}^{2+}$ and PS [55,57]. Treatment with DGK $\alpha$ inhibitors is reported to reduce the intracellular $\mathrm{Ca}^{2+}$ levels, which indicated that $\mathrm{Ca}^{2+}$ and DGK $\alpha$ are a part of a positive feedback loop [58]. PA activates DGK isoforms with high efficiency, which indicates the presence of a positive feedback mechanism [59-61]. PS treatment does not activate DGK $\delta$, while constitutive RhoA overexpression inhibits the activity of DGK $[60,62]$. PIP2, a precursor of DAG, inhibits the activity of DGK $\theta[63]$.

\subsection{Subcellular Localization}

The plasma membrane translocation has been suggested to determine the spatiotemporal activity of DGK isoforms. Treatment with phorbol ester induces the plasma membrane translocation of DGK $\delta$ [64], which is regulated by the classical PKC (cPKC)-catalyzed phosphorylation of Ser-22 and -26 in the PH domain [65]. Expression pattern and subcellular localization of DGK isoforms are presented in Table 1.

The type II DGK $(\delta$ and $\eta)$ isozymes share a protein-protein interacting region, called SAM domain. The dynamic polymerization of the SAM domain inhibits the plasma membrane translocation and the activity of DGK $[66]$. Agonist-induced phosphorylation regulates the translocation and activation of some DGK isoforms. $\mathrm{Ca}^{2+}$ treatment [20], purinergic receptor stimulation [67,68], and T cell receptor (TCR) stimulation [69] translocate DGK $\alpha$ to the plasma membrane. The plasma membrane translocation of DGK $\alpha$ is also dependent on the phosphorylation of Tyr-334 of human DGK $\alpha$ (Tyr-335 in mouse DGK $\alpha$ ) catalyzed by Src family tyrosine kinases (Src and Lck) [70], while the nuclear export of DGK $\alpha$ is dependent on the phosphorylation of Tyr-218 catalyzed by Src-activated c-Abl tyrosine kinase [71]. The vitamin E-induced phosphorylation of DGK $\alpha$, which is catalyzed by Src family tyrosine kinases, promotes the plasma membrane translocation and the activity of DGK $\alpha$ [72,73]. DGK $\alpha$ is transported to the nucleus from the cytoplasm under serum starvation conditions. Although the nuclear function of DGK $\alpha$ is not clear, the nuclear DGK $\alpha$ activity was reported to promote the proliferation of K562 cells by promoting the G1/S transition [74]. Additionally, DGK $\alpha$ stabilizes Src activation, which indicated that DGK $\alpha$ and Src are a part of a positive feedback loop [75]. Previous studies have also reported the translocation of DGK $\alpha$ [76], DGK $\gamma$ [77], DGK $\delta$ [60], DGK [78], DGK $\theta$ [60], and DGKı [79] from the cytosol to the nucleus.

Table 1. Expression pattern and subcellular localization of DGK isoforms.

\begin{tabular}{ccc}
\hline Isoform & Main tissue Expression & Subcellular Localization \\
\hline$\alpha$ & T cell [2], brain [4,80] & Plasma membrane and nucleus [24,76], cytoplasm [4,76] \\
\hline$\beta$ & Brain [5,81] & Cytoskeleton [6,24], perisynaptic membrane [81] \\
\hline$\gamma$ & Brain [6,7] & Golgi and nucleus [24,77] \\
\hline$\delta$ & Ubiquitous [8,82-84] & Cytoplasm [8,24,60,85], endoplasmic reticulum [24], endosomes [86], nucleus [60] \\
\hline$\eta$ & Ubiquitous [9,83,84,87] & Cytoplasm [9,87], endosomes [24] \\
\hline$\kappa$ & Reproductive organs [10,83,84] & Plasma membrane and endoplasmic reticulum [24,89] \\
\hline$\varepsilon$ & Ubiquitous [11,84,88] & Cytoplasm [90], plasma membrane and nucleus [24,78,91] \\
\hline$\xi$ & Ubiquitous [12,84] & Cytoplasm [90], nucleus [24,79]
\end{tabular}

\subsection{Transcriptional Control}

The expression of DGK $\alpha$ and DGK $\zeta$ is regulated at the transcriptional level [94]. The promoter of the DGK $\alpha$ gene contains a binding site for early growth response 2 (EGR2), which is a transcription factor (TF) that is upregulated upon TCR stimulation [95]. The upregulation of DGK $\alpha$ expression is important for T cell anergy [96]. Forkhead box O1 and 3 (FoxO1 and 3) TFs bind to the promoter of DGK $\alpha$ in the quiescent T cells. TCR stimulation decreases binding of FoxO TFs to the DGK $\alpha$ promoter, which results in decreased transcription of DGK $\alpha$. DGK $\zeta$ expression is also upregulated in the anergic cells through EGR2 [97]. DGK $\zeta$, which lacks the calcium-binding EF motif, is nonresponsive to $\mathrm{Ca}^{2+}$ 
signals and is activated through PKC-mediated phosphorylation. The nuclear export of DGK $\zeta$ is dependent on the PKC $\alpha$-mediated phosphorylation of its MARCKS homology domain [78,98].

\subsection{Post-Translational Control}

Norepinephrine stimulates the activity of DGK $\theta$ through a PI3K-dependent mechanism [99]. In the human adrenocortical cells, steroidogenic factor 1 and sterol regulatory element-binding protein 1 mediate the cyclic adenine monophosphate (cAMP)-induced expression of DGK $\theta$ [100]. The phosphorylation of Ser-776 and -779 in the accessory subdomain of DGK $\gamma$ is catalyzed by PKC $\gamma$ after purinergic stimulation, which enhances the enzyme activity [68]. PKC $\gamma$ directly interacts with DGK $\gamma$ through its accessory subdomain, which is dependent on $\mathrm{Ca}^{2+}, \mathrm{PS}$, and diolein. DGK negatively regulates PKC activation by downregulating the level of DAG. Polybasic proteins such as histone H1 and Tau stimulate DAG binding and catalytic activity of DGK $\theta$ [61].

\subsection{Inhibitors}

R59022, R59949, and ritanserin are allosteric inhibitors of DGK $\alpha$ [101]. They are also serotonin receptor antagonists. R59949 strongly inhibits type I DGKs ( $\alpha$ and $\gamma$ ) and moderately inhibits type II DGKs ( $\theta$ and $\kappa$ ) [102]. The half-maximal inhibitory concentration (IC50) values of R59022 and R59949 against DGK $\alpha$ are 25 and $18 \mu \mathrm{M}$, respectively [103]. R59022 and R59949 share a highly similar structure and the structure of R59022 differs by a single fluorine from ritanserin. The IC50 value of ritanserin against DGK $\alpha$ is approximately $20 \mu \mathrm{M}$. Recently, CU-3, a competitive ATP inhibitor, was identified as a novel DGK $\alpha$-selective inhibitor $(\mathrm{IC} 50=0.6 \mu \mathrm{M})$. The administration of CU-3 enhanced cancer cell apoptosis and immune responses in vitro $[103,104]$. However, the structure and reactivity of CU-3 are not suitable for in vivo applications. AMB639752 was recently identified as a novel DGK $\alpha$-selective inhibitor, devoid of serotoninergic activity, from an in-silico approach [105].

Hence, there is an urgent need to identify novel, specific, and potent small-molecule inhibitors of DGK isoforms. There are ongoing efforts to identify these inhibitors. However, the identification of DGK inhibitors is challenging because the catalytic domain of mammalian DGK has not yet been crystallized and the active sites of DGK are poorly characterized. The lack of crystal structures has seriously limited the mechanistic understanding of the interaction between substrate and inhibitor. Recently, a proteomic study identified the novel ligand-binding regions that mediate the binding of ATP and inhibitor to the poorly characterized active site of DGK isozymes [106]. Additionally, another study reported the crystal structure of EF-hand domains of DGK $\alpha$ in its $\mathrm{Ca}^{2+}$-bound form, which can regulate intra-molecular interactions [107].

\section{Signaling Pathways Regulated by DGK Isoforms}

Because DGK isoforms regulate multiple signaling pathways through the attenuation of DAG signaling and initiation of PA signaling pathways, the biological functions of DGKs can result from both DAG hydrolysis and enhanced PA biosynthesis. However, further studies are needed to delineate the processes responsible for the specific biological functions of DGKs.

The summary of representative DGK-regulated signaling pathways is shown in Figure 2. Activated PLC $\gamma 1$ cleaves PIP2 in the plasma membrane to generate two secondary messengers, DAG and IP3. DAG activates PKC, AP-1 and partly NF-KB and IP3 is involved in the activation of intracellular $\mathrm{Ca}^{2+}$ flux. The upregulated $\mathrm{Ca}^{2+}$ signaling activates the TF and NFAT. In the T cells, the antigen-stimulated DAG production is dependent on the strength of antigenic stimulation and determines the duration and intensity of the Ras/MEK/ERK and PKC-dependent signaling pathways (Figure 4). 


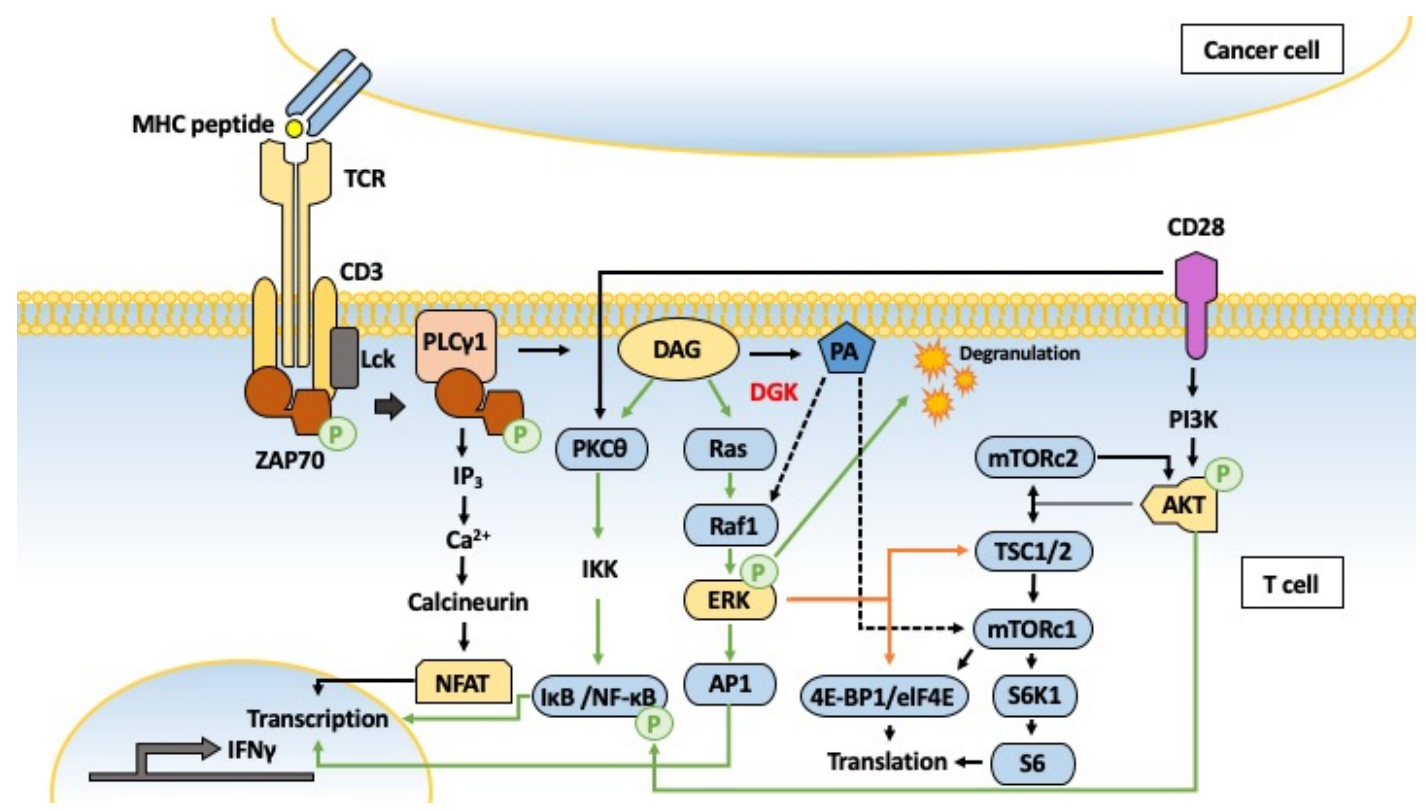

Figure 4. Representative signaling pathways regulated by diacylglycerol kinases (DGKs) in the activated T cells. Our understanding about diacylglycerol (DAG)-mediated regulation of Ras-MEK-ERK and PKC-NF- $\mathrm{kB}$ is majorly based on $\mathrm{T}$ cell biology. Immunological synapse formation between $\mathrm{T}$ cell and cancer cell is shown as a representative model here. Signals originating from T cell receptor (TCR) engagement of peptide/MHC complex in the presence of co-stimulatory signal lead to the recruitment of adaptor molecules and degranulation, which promote the lysis of the target cells and secretion of IFN $\gamma$ (T cell effector function). DGKs downregulate the levels of DAG, which activates the TCR distal signaling through Ras-ERK and NF- $\mathrm{BB}$ (green arrow). The biosynthesis of phosphatidic acid (PA) in the T cells is mediated by DGKs and phospholipase D (PLD) (not shown). PA is shown to activate Raf1 and mTORC1 in the immune and non-immune cells (dotted black arrow).

\subsection{Ras/MEK/ERK Pathway}

DGK $\alpha$ and DGK $\zeta$ negatively regulate $T$ cell response and induce T cell anergy [108-110]. IL-2 suppresses DGK $\alpha$ to restore the responsiveness in the anergic T cells [111]. DGK $\alpha$ and DGK $\zeta$ exhibit both redundant and specialized functions in the T cells, which limit the intensity of DAG-regulated signals downstream of the antigenic stimulation [112]. The binding of $\mathrm{Ca}^{2+}$ and PIP3 to EF-hands and C1 domain, respectively, and Src family kinase (Lck)-catalyzed tyrosine phosphorylation regulate the localization and activity of DGK $\alpha$ to the peripheral area of the immunological synapse. An immunological synapse is a specialized interface between a $\mathrm{T}$ cell and an antigen-presenting cell and consists of molecules involved in T cell activation. After the T-cell activation and CD-28 co-stimulation, the transcriptional suppression of DGK $\alpha$ is higher than that of DGK $\zeta$, which may be due to the PI3K-AKT signaling-mediated inhibition of FoxO-mediated transcription of DGK $\alpha$ [113]. The RASGRP/ERK pathway, which is activated by DAG, is crucial for the polarization of microtubule-organizing center in the cytotoxic $T$ cells, delivery of lytic granules to the immunological synapse, and the subsequent lytic attack on the target cells [114]. Recent studies have focused on the functions of DGK $\alpha$ and DGK $\zeta$, which are involved in TCR signaling. The function of DGK $\delta$ in the T cells has not been elucidated [94].

DGK isoforms also regulate the Ras/MEK/ERK pathway in non-immune cells. In contrast to the T cells in which DGK $\alpha$ inhibition activates the Ras pathway, the inhibition of DGK $\alpha$ suppresses Ras in the hepatocellular carcinoma cells. This suggested the differential effects of DGK $\alpha$ inhibition on different

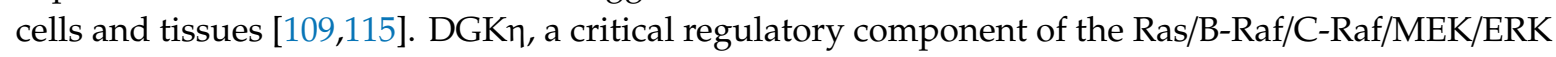
signaling cascade, mediates B-Raf/C-Raf-dependent cell proliferation [116]. DGK $\delta$ positively regulates epidermal growth factor receptor (EGFR) signaling [117]. The DGK $\delta$-deficient cells exhibit enhanced ubiquitination of EGFR owing to the decreased expression of ubiquitin-specific protease 8 (USP8), 
a deubiquitinase [118]. DGKı inhibits the RASGRP3-dependent Rap1 signaling pathway [119]. DGK $\gamma$ suppresses Rac1 and regulates the formation of lamellipodium [120].

In the tumor microenvironment (TME), the tumor-suppressive function of resident immune cells, such as macrophages and $\mathrm{T}$ cells, are switched to pro-tumoral functions [121]. The anergic $\mathrm{T}$ cells and tumor-infiltrating $\mathrm{T}$ cells are reported to exhibit similar properties, such as enhanced DGK $\alpha$ levels, attenuated ERK responses (both low basal phosphorylation of ERK and low stimulation-induced phosphorylation of ERK and c-JNK), and downregulated expression of AKT and AKT client proteins (two regulatory factors of NF-kB: IKB and GSK3) [122]. The high level of DGK $\alpha$ and inhibited MAPK pathways can lead to the dysfunction of human tumor-infiltrating CD8+ T cells (pro-tumoral), which is reversible upon treatment with low-dose of IL-2 to suppress DGK $\alpha$ [123]. DGK $\zeta$ is expressed in various hematological cells. The deficiency of DGK $\zeta$ is reported to be immunostimulatory in the T cells, natural killer (NK) cells, and B cell but immunosuppressive or modulatory in the Treg cells, mast cells, macrophage, and dendritic cells [124].

\subsection{NF- $\kappa B$ Signaling}

DGK $\zeta$ downregulates the p53-mediated cytotoxic responses [125] and cytokine-induced pro-inflammatory NF-kB signaling [126] in the HeLa cells. Additionally, DGK $\zeta$ downregulation shifts the limiting pool of $\mathrm{CBP} / \mathrm{p} 300$ coactivators toward the NF- $\mathrm{KB}$ p65 subunit from p53, which indicated the presence of reciprocal antagonistic phenotypes between p53 and NF-kB [127].

\subsection{Insulin Signaling}

PI3Ks bound to phosphorylated Ser of activated insulin receptor substrate (IRS) induce the plasma membrane translocation of glucose transporter type 4 (GLUT4), which facilitates glucose uptake [128]. ${ }_{\mathrm{cPKC}}(\alpha, \beta$ and $\gamma)$ and novel PKCs (nPKCs; $\delta, \varepsilon, \eta$, and $\left.\theta\right)$ are activated upon binding with sn-1,2 DAG. Consequently, PKC-phosphorylated IRS does not serve as a scaffold for PI3K and decreases glucose uptake. Consistent with these mechanistic insights, the mouse models and human mutations associated with increased DAG levels exhibited hyperglycemia and insulin resistance [129-134]. The activation of PKCs only by sn-1,2 DAG indicates the importance of identifying DAG isomerism under physiological and pathological conditions to elucidate the correlation between DAG levels and DAG signaling mediated by DAG, DGK, and DAG-targeted proteins, such as PKC. DGK $\delta$-mediated DAG degradation promotes the downregulation of PKC activity, which activates the insulin receptor signaling pathways [135].

\section{4. $G \alpha_{q}$ Regulation of PLC}

In the non-immune cells, allosteric regulation of PLC- $\beta 1$, which is activated by agonist-induced G protein-coupled receptor (GPCR), is required for its synergistic lipase-GAP activity. PA synthesized by RhoA-activated phospholipase D1 (PLD1) transduces signals through the unique PA-binding domain of PLC- $\beta 1$ to potentiate $G \alpha_{q}$-stimulated lipase activity of PLC. DAG-mediated PKC activity may limit the PA-mediated allosteric upregulation of PLC activity, which indicates that the complex regulation of PLC activity is dependent on the balance between DAG and PA [136,137].

\subsection{Hypoxic Responses and Angiogenesis}

Hypoxia promotes the accumulation of PA through the activation of DGKs [138]. The accumulated PA regulates the hypoxia-inducible factor (HIF)- $1 \alpha$ level [138]. Consistent with this finding, R59949 treatment strongly impaired hypoxia-induced accumulation of HIF-1 $\alpha$ [139]. The activation of DGK $\alpha$ activates both proliferative and migratory responses in the endothelial cells during vascular endothelial growth factor (VEGF)-induced angiogenesis [140]. R59949 treatment inhibits inducible nitric oxide production in the vascular smooth cells through the inhibition of L-arginine uptake [141]. Additionally, R59949 suppresses retinal neovascularization and protects the retinal astrocytes in an oxygen-induced retinopathy model [142]. This further suggested the role of DGKs, especially DGK $\alpha$, in regulating 
angiogenesis. Under hyperglycemic conditions, de novo synthesis of DAG activates PKC in the glomerulus, which activates the vicious cycle of PKC-ROS loop [143].

\subsection{Endosomal Trafficking}

Recently, DGKs were reported to regulate endosomal trafficking [144]. DGK isoforms regulate various stages of the endocytic trafficking, through the metabolic conversion of DAG to PA, including endocytosis, recycling endosomes, recycling of integrin and MHC complex, transporting from/to the Golgi apparatus, and the formation and secretion of multivesicular bodies [145-148]. DAG regulates membrane trafficking through the following mechanisms: activation of PKC, PKD, and downstream signaling cascades [149-152]; regulation of PI cycle to maintain the levels of PIP2, IP3, and $\mathrm{Ca}^{2+}$ influx; promoting membrane fusion and fission through the conical-shaped DAG provision of negative membrane curvature $[153,154]$. The spatial concentration of PA is also an important regulator of trafficking [144]. Recent studies have suggested a novel mechanism for the limited PKC $\alpha$ activation in the T cells, which involves the interaction between DGK $\zeta$ and Sorting Nexin 27 [155]. This suggested that DGK $\zeta$ deficit may also contribute to the pathogenesis of Alzheimer's disease through the dysregulation of PKC activity. DGK $\zeta$-mediated activation of Rac1, a Rho GTPase family protein, plays a pivotal role in macropinocytosis and phagocytosis [156].

\section{7. mTOR Signaling}

In addition to DGKs, various enzymes catalyze the biosynthesis of PA [54]. For example, PA is produced from PLD-catalyzed hydrolysis of PLs, such as PC or PE (Figure 3). PLD-generated PA (PLD-PA) is one positive input for mTOR signaling [157]. PA-dependent activation of mTORC1 is mediated through the Raf-ERK pathway [158] or direct binding of PA to mTORC1, followed by displacement of inhibitory FKBP38 from mTORC1, and allosteric stimulation of the catalytic activity of mTORC1 [159]. In the T cells, TCR engagement and DAG activate the mTOR signaling through mTORC1 and 2 from the Ras-MEK1/2-ERK1/2 pathway. DGK $\alpha$ and $\zeta$ synergistically inhibit TCR-induced mTOR activation by inhibiting the Ras-MEK1/2-ERK1/2 pathway [160]. Thus, DGKs can inhibit mTOR signaling and both DAG and PA function as agonists of mTOR signaling in the T cells.

\subsection{Different Effects of PAs Produced by DGK and PLD}

At the sn- 1 and -2 positions, DAG and PA contain different acyl chains. Thus, some studies have suggested that mammalian cells have more than 50 structurally distinct DAG/PA species [27]. However, the effect of different DAG/PA species on various cellular signaling events is unclear. The major PA species produced by PLD activity is 36:1 PA [161], while those produced by DGKs are 38:3, 38:4, and 38:5 PA [147]. Various PA species are reported to exhibit differential degrees of interaction and/or activation of the target proteins.

For example, Rab-coupling protein (RCP) must bind to PA to be tethered at the tips of invadopodia. The inhibition of DGK $\alpha$ inhibited the recruitment of RCP to allow $\alpha 5 \beta 1$ integrin recycling and promote the invasiveness of tumor cells, while the inhibition of PLD, which also generates PA, did not affect its recruitment [147]. Thus, DGK $\alpha$ is more important than PLD for RCP functions as a source of PA. DGK-generated PA (DGK-PA) is also involved in anti-neutrophil cytoplasmic antibody (ANCA)-driven granule exocytosis and adhesion of leukocytes $[162,163]$.

PLD-PA is reported to be involved in cell invasion and tumor metastasis. The spatial production of PA by PLD is important for regulating microtubule-based and kinesin-based trafficking of endosomes containing prometastatic MT1-MMP for the secretion at invadopodia [52]. The PLD-catalyzed PA production is mediated through the hydrolytic cleavage of PC or PE. PLD-PA directly binds LATS and NF2, inhibits LATS-MOB1 complex formation, and promotes NF2-mediated membrane translocation and activation of LATS [164]. This PLD-PA driven inhibition of Hippo signaling activates the oncogenic Yes-associated protein and transcriptional coactivator with PDZ-binding motif (YAP/TAZ) signaling (PLD-PA-YAP signaling axis). Although a DAG analog, 12-O-tetradecanoyl-phorbol-13-acetate 
upregulates YAP/TAZ signaling through PKC activation [165], the role of DGK-PA in regulating YAP/TAZ signaling is not reported. These findings indicate that the increased or decreased pool of PA produced from the upregulation of DGKs or LIPINs may not regulate YAP/TAZ signaling.

\section{Pathological Manifestations}

Studies on DGK KO mice demonstrated the importance of DGKs in the immune system [96], and their pathophysiological roles in the brain and heart [166], insulin resistance in diabetes [167], and Friedrich's ataxia [168]. Toxoplasma gondii-secreted DGK orthologs were demonstrated to function as key upstream activators of the programmed egress of the parasite from the host cells [169]. Recent studies have demonstrated the differential roles of several DGK isoforms in human diseases. DGK deficiency is directly or indirectly involved in human diseases, such as cancer, atypical hemolytic uremic syndrome, hypospadias (DGKK) [170], diabetes, and mood and cognitive disorders, including Parkinson's disease and fragile $X$ syndrome, a primary cause of autism and inherited cognitive disorder [168]. Currently, the closest association between the loss-of-function mutation and human disease appears to be observed from DGK $\varepsilon$ [16]. Recessive mutations of DGK $\varepsilon$ are associated with atypical hemolytic uremic syndrome, a disease characterized by renal vascular endothelial injury due to diminished poly-unsaturated fatty acids, which are required for prostanoid synthesis [171,172]. Genome-wide association studies (GWASs) have also revealed the correlation between diseases and other DGK isoforms [19].

\subsection{Cancer}

DGKs are reported to be involved in cancer progression. Several studies have reported that DGK $\alpha$ is involved in cancer progression. However, the function of DGK $\alpha$ in cancer is controversial as it might also function as a tumor suppressor. DGK $\alpha$ exhibits pro-tumoral, anti-immunogenic, and fibroblast-activating properties, which indicated that selective inhibitors of DGK $\alpha$ can simultaneously exert antitumoral and pro-immunogenic effects in the TME [19,96,173-175]. The pro-tumoral hypoxic and immunosuppressive TME upregulates DGK $\alpha$ in the cancer and infiltrating T cells. Additionally, DGK $\alpha$ stabilizes oncogenic Src activation. The upregulated DGK $\alpha$ expression is required for the growth and survival of highly metastatic cancer cells but not for those of non-transformed primary cells [75]. However, recent studies have also demonstrated the anti-tumoral effect of DGK $\alpha$ in different cancer types [16,176-178]. Thus, DGK $\alpha$ appears to be both pro- and anti-tumoral depending on cancer cell-context.

Additionally, some cancers are dependent on DGK $\alpha$-regulated pathways, which promote cancer cell survival [179]. DGK $\alpha$, a positive regulator of NF- $\mathrm{B}$, suppresses tumor necrosis factor- $\alpha$-induced apoptosis in the human melanoma cells through the activation of NF- $\mathrm{KB}$ [180]. The pro-tumoral function of DGK $\alpha$ is not reported for other DGK isoforms.

Decreased DNA methylation at the enhancer region of DGK $\alpha$ promotes the recruitment of the profibrotic TF, EGR1, and radiation-induced transcription of DGK $\alpha$, which results in the profibrotic pathway activation in the dermal fibroblasts derived from patients who later developed fibrosis [175]. The role of DGK $\alpha$ in the generation of cancer-associated fibroblasts in the TME has not been elucidated. The analysis of epigenetic silencing revealed that the methylation of the DGK $\gamma$ promoter is positively correlated with KRAS and BRAF mutations and that the methylation is frequently observed in colorectal adenomas, which suggested the significance of methylation in early colorectal tumorigenesis [181]. Consistent with this finding, the downregulated expression of DGK $\alpha$ synergizes with oncogenic mutations of p53 and Ras genes to promote transformation [16,176-178].

It has been shown that DGKı and DGK $\delta$ are involved in anchorage-independent growth and motility of Kaposi sarcoma cells in response to hepatocyte growth factor, respectively [182]. DGK $\zeta$, which is necessary for the growth and survival of glioma cells [183], promotes invasiveness [184] and lipogenic metabolism, as well as the growth of colon cancer cells [185]. 


\subsection{Diabetes and Its Complications}

DGK isoforms are reported to exhibit both pro-diabetic and anti-diabetic properties. The DAG-PKC pathway is involved in the pathogenesis of diabetic microvasculature complications [186]. The complications include nephropathy, neuropathy, and retinopathy that are associated with hyperglycemia (it may be necessary, but not sufficient to trigger the complications), oxidative stress, and mitochondrial dysfunction [187]. PKC activation decreases glucose uptake, upregulates the expression of profibrotic TGF- $\beta 1$, and increases the production of the extracellular matrix, which contribute to the progression of renal insufficiency. As DGK negatively regulates PKC activation, dysfunction of several DGK isoforms may exacerbate diabetic phenotypes. The deficiency of DGK $\delta$ promoted hyperglycemia-induced peripheral insulin resistance and exacerbated the severity of type II diabetes [167]. Vitamin E (D- $\alpha$-tocopherol)-activated DGK $\alpha$ is involved in the vitamin E-induced alleviation of diabetic nephropathy in vivo [73] and regulates the immune responses in the white adipose tissue [188]. DGK $\gamma$ regulates insulin secretion [189].

Different DGK isoforms are reported to exhibit pro-diabetic properties. DGK $\varepsilon$ deficiency preserves glucose tolerance and increases lipid metabolism in obese mice [190]. DGK $\zeta$ KO mice were protected against peripheral insulin resistance and showed increased respiratory exchange ratio [191]. These findings suggest the need to differentiate the non-redundant signaling pathways regulated by pro-diabetic and anti-diabetic DGK isoforms for developing potential diabetes therapeutics.

\subsection{Cognition and Mood Impairment}

Fragile $X$ mental retardation protein (FMRP) regulates DGKk expression in the neurons. In fragile $\mathrm{X}$ syndrome, a condition in which FMRP-dependent DGK $\kappa$ translation does not occur, DAG generated from the activation of metabotropic glutamate receptor mGluRI, a GPCR, is not transformed into PA in neurons [168]. GWAS have suggested that DGK $\theta$ is associated with the pathogenesis of Parkinson's disease [192,193].

Studies on KO mice have demonstrated that several DGK isoforms regulate brain function through the direct regulation of synaptic plasticity [194]. DGK $\beta$ is a learning-regulated gene in humans [195]. DGK $\beta$ KO mice exhibited impaired cognitive functions, including impaired spatial and long-term memories [196] and bipolar disorder-like phenotypes [196,197]. The administration of lithium alleviated the impairment of memory and emotion in the DGK $\beta$ KO mice [198], which suggested that the expression level of DGK $\beta$ is a putative biomarker for screening patients with lithium-responsive bipolar disorder.

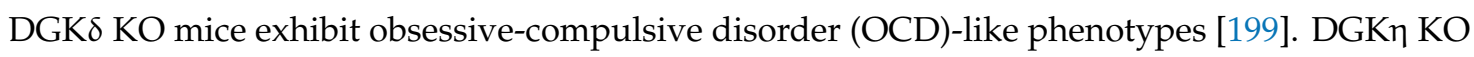
mice exhibited bipolar disorder (mania)-like phenotypes, which was alleviated upon lithium administration [200]. DGKe regulates seizure susceptibility and long-term memories [88]. Additionally, DGK $\varepsilon$ has been suggested to contribute to the pathogenesis of Huntington disease [201].

DGK $\zeta$ is targeted to excitatory synapses through the direct interaction with postsynaptic density protein-95 (PSD-95). Previous studies have reported that DGK $\zeta$ deficiency leads to decreased spine density [202], impaired bone resorption, and reduced muscle hypertrophy [157]. However, DGK $\zeta$ gene mutations have not been reported in humans.

\subsection{Inflammation and Immunity}

The inhibition of DGK $\alpha$ and DGK $\zeta$ enhances the T cell antitumor response and the efficacy of immunotherapies, such as chimeric antigen receptor-modified T (CAR-T) cell therapy [203]. Genetic ablation of DGK $\zeta$ results in hyperresponsive NK cells, which exhibit increased cytokine production and degranulation through an ERK-dependent mechanism [110]. DGK $\alpha$ inhibition can restore the impaired functions of T cells and NK cells.

The targeted deletion of DGK $\zeta$ in the T cells decreases type 2 inflammation without reducing airway hyperresponsiveness (AHR). However, the loss of DGK $\zeta$ in the airway smooth muscle cells decreases 
AHR but not airway inflammation [204]. DGK $\zeta$ was reported to limit the inflammatory cytokine production and pro-inflammatory M1-like macrophage polarization through the downregulation of STAT1 and STAT3 phosphorylation in the cytokine storm syndrome mouse model, which was dependent on TLR9 signaling, and the arthritic mouse model, which was dependent on TLR2 signaling [205]. The DGK $\zeta$-deficient mast cells exhibit impaired degranulation, increased IL-6 secretion, and upregulated Ras/AKT/ERK signaling [206]. DGK $\gamma$ regulates the antigen-induced degranulation of the mast cells through the modulation of $\mathrm{Ca}^{2+}$ influx [207].

The activation of cPKC and RASGRP4 in the neutrophils, which are downstream effectors of DAG signaling, promotes NADPH oxidase activity, leukocyte movement, and extracellular trap release (NETosis) [104,208]. The activation of cPKC by PMA, a DAG analog, promotes NET formation. However, there are no in vitro or in vivo studies examining the direct regulation of NETosis by DGK. Additionally, there are limited studies on the biological role of DGK $\alpha$ in the immune cells other than the T cells. However, increasing evidence indicates that DGK $\alpha$ regulates leukocyte function [209]. The stimulation of human neutrophils with $\mathrm{N}$-formylmethionine-leucyl-phenylalanine promotes DAG production, most of which is metabolized by DGK $\alpha$. Treatment with R59022 enhances the DAG levels, which indicated that the inhibition of DGK $\alpha$ is required for neutrophil activation [210]. ANCAs target myeloperoxidase and proteinase 3 to promote adhesion, degranulation, and oxidative burst in the neutrophils. The neutrophils incubated with R59022 before treatment with ANCAs exhibited a decreased release of azurophilic granules containing cytotoxic factors, such as proteases and myeloperoxidase, which is caused due to the inhibition of granule fusion at the plasma membrane [163]. This inhibition is restored by PA treatment, which indicated that DGK $\alpha$ upregulates granule exocytosis.

\section{Conclusions}

Studies on the regulation of DAG/PA levels by various enzymes, the identification and characterization of various DAG/PA-regulated proteins, and the overlap of different DAG/PA metabolic and signaling processes have revealed the complex roles of DGKs in regulating multiple biochemical and biological networks. However, the existence of many isomeric forms of DAG/PA, non-redundant functions and versatile subcellular localization of DGKs, and multiple signaling pathways regulated by DGKs impede our efforts to delineate the specific contribution of each DGK isoform in maintaining cellular homeostasis. Thus, further studies are necessary to characterize the physiological functions of DGK isoforms in the cells of the tissue microenvironment to develop therapeutic agents for pathological conditions associated with dysregulated downstream oncogenic pathways, immunity, and angiogenesis.

Lipid metabolism is a dynamic, complex, and bi-directional process. Hence, the functions of DGK isoforms are also dependent on their interaction with other lipid-modifying enzymes. Currently, there are no known inhibitors of DGK isoforms, except DGK $\alpha$. The known inhibitors of DGK $\alpha$ are not selective. In contrast, several inhibitors of PA-synthesizing LPAAT and PLD have been reported. The precise modulation of PA synthesis using a combination of inhibitors of multiple DGK isoforms and PA synthesis enzymes may improve the therapeutic efficacy against cancer. Further studies are needed to explore these therapeutic strategies.

However, the successful lab-to-clinic translation will need the identification of novel specific inhibitors of DGK isoforms and the elucidation of mechanisms that regulate the function and expression of DGK isoforms and signaling events comprising direct targets and effectors of DGK isoforms. The biological functions of DGK isoforms have been mostly explored in the immune and nervous systems, while lab-to-clinic translation efforts have mainly focused on cancer. Future studies must correlate laboratory and preclinical findings with the clinical findings.

We expect that the simultaneous functional comparisons of inhibition of DGK isoforms can delineate the specific contribution of each isoform in maintaining homeostasis, which will promote the restoration or maintenance of tissue microenvironment. 
Funding: This work was supported by the Basic Science Research Program, through the National Research Foundation of Korea (NRF), funded by the Ministry of Science, ICT and Future Planning (NRF-2020R1F1A1071980 and NRF-2018R1D1A1B07041381).

Conflicts of Interest: The authors declare no conflict of interest. The funders had no role in the design of the study; in the collection, analyses, or interpretation of data; in the writing of the manuscript, or in the decision to publish the results.

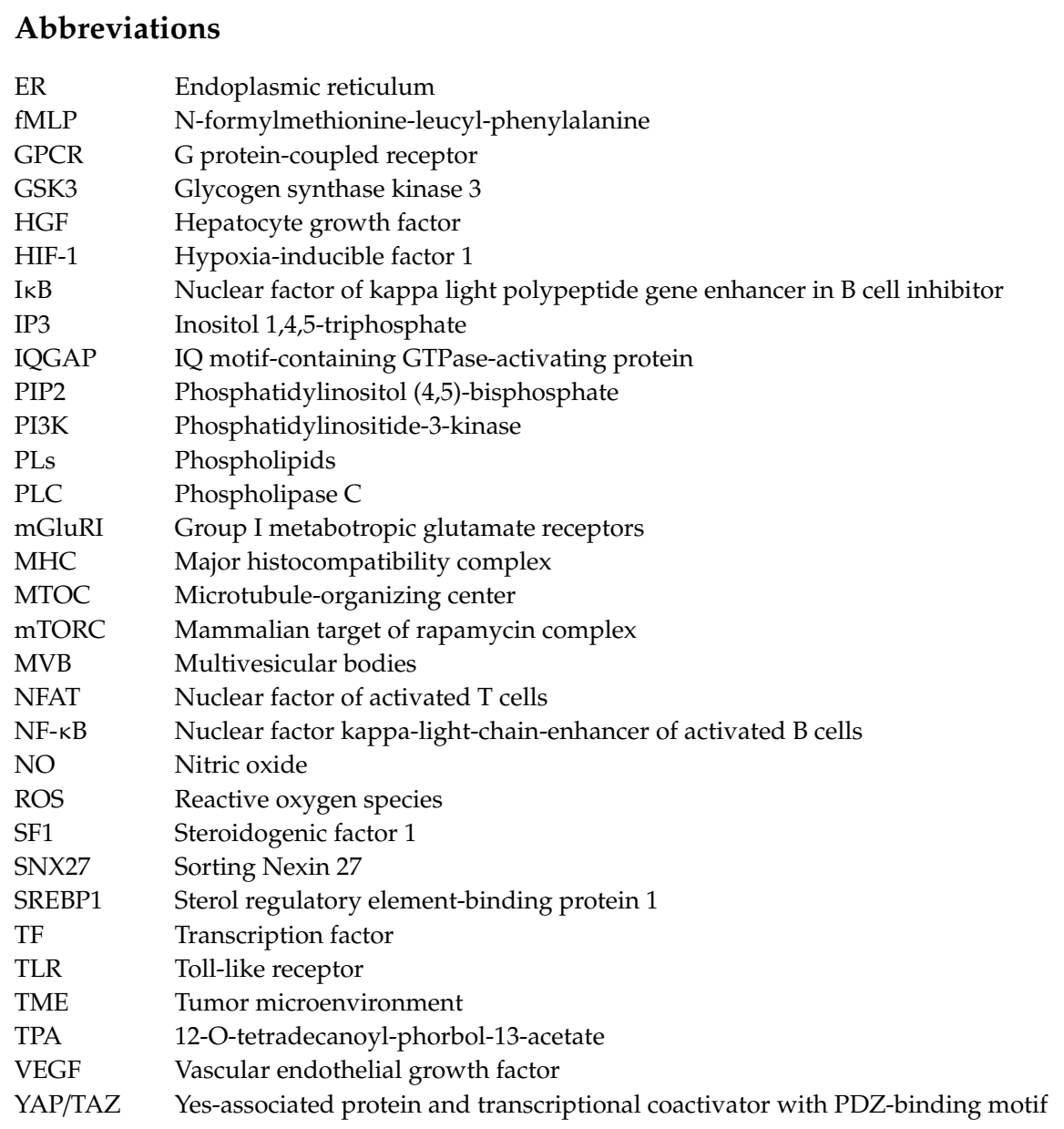

\section{References}

1. Kanoh, H.; Kondoh, H.; Ono, T. Diacylglycerol kinase from pig brain. Purification and phospholipid dependencies. J. Biol. Chem. 1983, 258, 1767-1774. [PubMed]

2. Schaap, D.; de Widt, J.; van der Wal, J.; Vandekerckhove, J.; van Damme, J.; Gussow, D.; Ploegh, H.L.; van Blitterswijk, W.J.; van der Bend, R.L. Purification, cDNA-cloning and expression of human diacylglycerol kinase. FEBS Lett. 1990, 275, 151-158. [CrossRef]

3. Hart, T.C.; Champagne, C.; Zhou, J.; Van Dyke, T.E. Assignment of the gene for diacylglycerol kinase (DAGK) to human chromosome 12. Mamm. Genome 1994, 5, 123-124. [CrossRef] [PubMed]

4. Sakane, F.; Yamada, K.; Kanoh, H.; Yokoyama, C.; Tanabe, T. Porcine diacylglycerol kinase sequence has zinc finger and E-F hand motifs. Nature 1990, 344, 345-348. [CrossRef]

5. Goto, K.; Kondo, H. Molecular cloning and expression of a 90-kDa diacylglycerol kinase that predominantly localizes in neurons. Proc. Natl. Acad. Sci. USA 1993, 90, 7598-7602. [CrossRef]

6. Goto, K.; Funayama, M.; Kondo, H. Cloning and expression of a cytoskeleton-associated diacylglycerol kinase that is dominantly expressed in cerebellum. Proc. Natl. Acad. Sci. USA 1994, 91, 13042-13046. [CrossRef]

7. Kai, M.; Sakane, F.; Imai, S.; Wada, I.; Kanoh, H. Molecular cloning of a diacylglycerol kinase isozyme predominantly expressed in human retina with a truncated and inactive enzyme expression in most other human cells. J. Biol. Chem. 1994, 269, 18492-18498. 
8. Sakane, F.; Imai, S.; Kai, M.; Wada, I.; Kanoh, H. Molecular cloning of a novel diacylglycerol kinase isozyme with a pleckstrin homology domain and a C-terminal tail similar to those of the EPH family of protein-tyrosine kinases. J. Biol. Chem. 1996, 271, 8394-8401. [CrossRef]

9. Klauck, T.M.; Xu, X.; Mousseau, B.; Jaken, S. Cloning and characterization of a glucocorticoid-induced diacylglycerol kinase. J. Biol. Chem. 1996, 271, 19781-19788. [CrossRef]

10. Imai, S.; Kai, M.; Yasuda, S.; Kanoh, H.; Sakane, F. Identification and characterization of a novel human type II diacylglycerol kinase, DGK kappa. J. Biol. Chem. 2005, 280, 39870-39881. [CrossRef]

11. Tang, W.; Bunting, M.; Zimmerman, G.A.; McIntyre, T.M.; Prescott, S.M. Molecular cloning of a novel human diacylglycerol kinase highly selective for arachidonate-containing substrates. J. Biol. Chem. 1996, 271, 10237-10241. [CrossRef] [PubMed]

12. Bunting, M.; Tang, W.; Zimmerman, G.A.; McIntyre, T.M.; Prescott, S.M. Molecular cloning and characterization of a novel human diacylglycerol kinase zeta. J. Biol. Chem. 1996, 271, 10230-10236. [CrossRef]

13. Ding, L.; Traer, E.; McIntyre, T.M.; Zimmerman, G.A.; Prescott, S.M. The cloning and characterization of a novel human diacylglycerol kinase, DGKiota. J. Biol. Chem. 1998, 273, 32746-32752. [CrossRef] [PubMed]

14. Houssa, B.; Schaap, D.; van der Wal, J.; Goto, K.; Kondo, H.; Yamakawa, A.; Shibata, M.; Takenawa, T.; van Blitterswijk, W.J. Cloning of a novel human diacylglycerol kinase (DGKtheta) containing three cysteine-rich domains, a proline-rich region, and a pleckstrin homology domain with an overlapping Ras-associating domain. J. Biol. Chem. 1997, 272, 10422-10428. [CrossRef] [PubMed]

15. Barber, C.N.; Raben, D.M. Roles of DGKs in neurons: Postsynaptic functions? Adv. Biol. Regul. 2020, 75, 100688. [CrossRef]

16. Merida, I.; Arranz-Nicolas, J.; Torres-Ayuso, P.; Avila-Flores, A. Diacylglycerol Kinase Malfunction in Human Disease and the Search for Specific Inhibitors. Handb. Exp. Pharmacol. 2020, 259, 133-162. [CrossRef]

17. Merida, I.; Avila-Flores, A.; Merino, E. Diacylglycerol kinases: At the hub of cell signalling. Biochem. J. 2008, 409, 1-18. [CrossRef]

18. Krishna, S.; Zhong, X.P. Regulation of Lipid Signaling by Diacylglycerol Kinases during T Cell Development and Function. Front. Immunol. 2013, 4, 178. [CrossRef]

19. Sakane, F.; Mizuno, S.; Komenoi, S. Diacylglycerol Kinases as Emerging Potential Drug Targets for a Variety of Diseases: An Update. Front. Cell Dev. Biol. 2016, 4, 82. [CrossRef]

20. Sakane, F.; Yamada, K.; Imai, S.; Kanoh, H. Porcine 80-kDa diacylglycerol kinase is a calcium-binding and calcium/phospholipid-dependent enzyme and undergoes calcium-dependent translocation. J. Biol. Chem. 1991, 266, 7096-7100.

21. Sanjuan, M.A.; Jones, D.R.; Izquierdo, M.; Merida, I. Role of diacylglycerol kinase alpha in the attenuation of receptor signaling. J. Cell Biol. 2001, 153, 207-220. [CrossRef] [PubMed]

22. Gupta, R.S.; Epand, R.M. Phylogenetic analysis of the diacylglycerol kinase family of proteins and identification of multiple highly-specific conserved inserts and deletions within the catalytic domain that are distinctive characteristics of different classes of DGK homologs. PLoS ONE 2017, 12, e0182758. [CrossRef] [PubMed]

23. Topham, M.K.; Prescott, S.M. Mammalian diacylglycerol kinases, a family of lipid kinases with signaling functions. J. Biol. Chem. 1999, 274, 11447-11450. [CrossRef] [PubMed]

24. Shulga, Y.V.; Topham, M.K.; Epand, R.M. Regulation and functions of diacylglycerol kinases. Chem. Rev. 2011, 111, 6186-6208. [CrossRef]

25. Kazanietz, M.G. Novel "nonkinase" phorbol ester receptors: The C1 domain connection. Mol. Pharmacol. 2002, 61, 759-767. [CrossRef]

26. Goldschmidt, H.L.; Tu-Sekine, B.; Volk, L.; Anggono, V.; Huganir, R.L.; Raben, D.M. DGKtheta Catalytic Activity Is Required for Efficient Recycling of Presynaptic Vesicles at Excitatory Synapses. Cell Rep. 2016, 14, $200-207$. [CrossRef]

27. Sakane, F.; Mizuno, S.; Takahashi, D.; Sakai, H. Where do substrates of diacylglycerol kinases come from? Diacylglycerol kinases utilize diacylglycerol species supplied from phosphatidylinositol turnover-independent pathways. Adv. Biol. Regul. 2018, 67, 101-108. [CrossRef]

28. Ganesan, S.; Shabits, B.N.; Zaremberg, V. Tracking Diacylglycerol and Phosphatidic Acid Pools in Budding Yeast. Lipid Insights 2015, 8, 75-85. [CrossRef]

29. Eichmann, T.O.; Lass, A. DAG tales: The multiple faces of diacylglycerol-stereochemistry, metabolism, and signaling. Cell. Mol. Life Sci. 2015, 72, 3931-3952. [CrossRef] 
30. Eichmann, T.O.; Kumari, M.; Haas, J.T.; Farese, R.V., Jr.; Zimmermann, R.; Lass, A.; Zechner, R. Studies on the substrate and stereo/regioselectivity of adipose triglyceride lipase, hormone-sensitive lipase, and diacylglycerol-O-acyltransferases. J. Biol. Chem. 2012, 287, 41446-41457. [CrossRef]

31. Shulga, Y.V.; Topham, M.K.; Epand, R.M. Study of arachidonoyl specificity in two enzymes of the PI cycle. J. Mol. Biol. 2011, 409, 101-112. [CrossRef]

32. Goto, K.; Hozumi, Y.; Nakano, T.; Saino-Saito, S.; Martelli, A.M. Lipid messenger, diacylglycerol, and its regulator, diacylglycerol kinase, in cells, organs, and animals: History and perspective. Tohoku J. Exp. Med. 2008, 214, 199-212. [CrossRef] [PubMed]

33. Nishizuka, Y. Intracellular signaling by hydrolysis of phospholipids and activation of protein kinase C. Science 1992, 258, 607-614. [CrossRef] [PubMed]

34. Carrasco, S.; Merida, I. Diacylglycerol-dependent binding recruits PKCtheta and RasGRP1 C1 domains to specific subcellular localizations in living T lymphocytes. Mol. Biol. Cell 2004, 15, 2932-2942. [CrossRef]

35. Spitaler, M.; Emslie, E.; Wood, C.D.; Cantrell, D. Diacylglycerol and protein kinase D localization during T lymphocyte activation. Immunity 2006, 24, 535-546. [CrossRef]

36. Siliceo, M.; Garcia-Bernal, D.; Carrasco, S.; Diaz-Flores, E.; Coluccio Leskow, F.; Teixido, J.; Kazanietz, M.G.; Merida, I. Beta2-chimaerin provides a diacylglycerol-dependent mechanism for regulation of adhesion and chemotaxis of T cells. J. Cell Sci. 2006, 119, 141-152. [CrossRef]

37. Song, Y.; Ailenberg, M.; Silverman, M. Human munc13 is a diacylglycerol receptor that induces apoptosis and may contribute to renal cell injury in hyperglycemia. Mol. Biol. Cell 1999, 10, 1609-1619. [CrossRef] [PubMed]

38. Lucas, P.; Ukhanov, K.; Leinders-Zufall, T.; Zufall, F. A diacylglycerol-gated cation channel in vomeronasal neuron dendrites is impaired in TRPC2 mutant mice: Mechanism of pheromone transduction. Neuron 2003, 40, 551-561. [CrossRef]

39. Hall, C.; Lim, L.; Leung, T. C1, see them all. Trends Biochem. Sci. 2005, 30, 169-171. [CrossRef]

40. Yang, C.; Kazanietz, M.G. Divergence and complexities in DAG signaling: Looking beyond PKC. Trends Pharmacol. Sci. 2003, 24, 602-608. [CrossRef]

41. Kassas, N.; Tanguy, E.; Thahouly, T.; Fouillen, L.; Heintz, D.; Chasserot-Golaz, S.; Bader, M.F.; Grant, N.J.; Vitale, N. Comparative Characterization of Phosphatidic Acid Sensors and Their Localization during Frustrated Phagocytosis. J. Biol. Chem. 2017, 292, 4266-4279. [CrossRef]

42. Jang, J.H.; Lee, C.S.; Hwang, D.; Ryu, S.H. Understanding of the roles of phospholipase D and phosphatidic acid through their binding partners. Prog. Lipid Res. 2012, 51, 71-81. [CrossRef]

43. Pokotylo, I.; Kravets, V.; Martinec, J.; Ruelland, E. The phosphatidic acid paradox: Too many actions for one molecule class? Lessons from plants. Prog. Lipid Res. 2018, 71, 43-53. [CrossRef] [PubMed]

44. Foster, D.A. Regulation of mTOR by phosphatidic acid? Cancer Res. 2007, 67, 1-4. [CrossRef] [PubMed]

45. Jenkins, G.H.; Fisette, P.L.; Anderson, R.A. Type I phosphatidylinositol 4-phosphate 5-kinase isoforms are specifically stimulated by phosphatidic acid. J. Biol. Chem. 1994, 269, 11547-11554.

46. Limatola, C.; Schaap, D.; Moolenaar, W.H.; van Blitterswijk, W.J. Phosphatidic acid activation of protein kinase C-zeta overexpressed in COS cells: Comparison with other protein kinase $\mathrm{C}$ isotypes and other acidic lipids. Biochem. J. 1994, 304 Pt 3, 1001-1008. [CrossRef]

47. Jones, J.A.; Hannun, Y.A. Tight binding inhibition of protein phosphatase-1 by phosphatidic acid. Specificity of inhibition by the phospholipid. J. Biol. Chem. 2002, 277, 15530-15538. [CrossRef] [PubMed]

48. Zhang, Y.; Du, G. Phosphatidic acid signaling regulation of Ras superfamily of small guanosine triphosphatases. Biochim. Biophys. Acta 2009, 1791, 850-855. [CrossRef]

49. Consonni, S.V.; Gloerich, M.; Spanjaard, E.; Bos, J.L. cAMP regulates DEP domain-mediated binding of the guanine nucleotide exchange factor Epac1 to phosphatidic acid at the plasma membrane. Proc. Natl. Acad. Sci. USA 2012, 109, 3814-3819. [CrossRef]

50. Simons, M.; Gault, W.J.; Gotthardt, D.; Rohatgi, R.; Klein, T.J.; Shao, Y.; Lee, H.J.; Wu, A.L.; Fang, Y.; Satlin, L.M.; et al. Electrochemical cues regulate assembly of the Frizzled/Dishevelled complex at the plasma membrane during planar epithelial polarization. Nat. Cell Biol. 2009, 11, 286-294. [CrossRef]

51. Jones, G.A.; Carpenter, G. The regulation of phospholipase C-gamma 1 by phosphatidic acid. Assessment of kinetic parameters. J. Biol. Chem. 1993, 268, 20845-20850. [PubMed]

52. Wang, Z.; Zhang, F.; He, J.; Wu, P.; Tay, L.W.R.; Cai, M.; Nian, W.; Weng, Y.; Qin, L.; Chang, J.T.; et al. Binding of PLD2-Generated Phosphatidic Acid to KIF5B Promotes MT1-MMP Surface Trafficking and Lung Metastasis of Mouse Breast Cancer Cells. Dev. Cell 2017, 43, 186-197.e7. [CrossRef] [PubMed] 
53. Wang, X.; Devaiah, S.P.; Zhang, W.; Welti, R. Signaling functions of phosphatidic acid. Prog. Lipid Res. 2006, 45, 250-278. [CrossRef]

54. Thakur, R.; Naik, A.; Panda, A.; Raghu, P. Regulation of Membrane Turnover by Phosphatidic Acid: Cellular Functions and Disease Implications. Front. Cell Dev. Biol. 2019, 7, 83. [CrossRef] [PubMed]

55. Shirai, Y.; Saito, N. Diacylglycerol kinase as a possible therapeutic target for neuronal diseases. J. Biomed. Sci. 2014, 21, 28. [CrossRef]

56. Cipres, A.; Carrasco, S.; Merino, E.; Diaz, E.; Krishna, U.M.; Falck, J.R.; Martinez, A.C.; Merida, I. Regulation of diacylglycerol kinase alpha by phosphoinositide 3-kinase lipid products. J. Biol. Chem. 2003, 278, 35629-35635. [CrossRef]

57. Takahashi, M.; Yamamoto, T.; Sakai, H.; Sakane, F. Calcium negatively regulates an intramolecular interaction between the $\mathrm{N}$-terminal recoverin homology and EF-hand motif domains and the C-terminal C1 and catalytic domains of diacylglycerol kinase alpha. Biochem. Biophys. Res. Commun. 2012, 423, 571-576. [CrossRef]

58. Marumo, M.; Nakano, T.; Takeda, Y.; Goto, K.; Wakabayashi, I. Inhibition of thrombin-induced Ca(2)(+) influx in platelets by R59949, an inhibitor of diacylglycerol kinase. J. Pharm. Pharmacol. 2012, 64, 855-861. [CrossRef]

59. Ostroski, M.; Tu-Sekine, B.; Raben, D.M. Analysis of a novel diacylglycerol kinase from Dictyostelium discoideum: DGKA. Biochemistry 2005, 44, 10199-10207. [CrossRef]

60. Bregoli, L.; Baldassare, J.J.; Raben, D.M. Nuclear diacylglycerol kinase-theta is activated in response to alpha-thrombin. J. Biol. Chem. 2001, 276, 23288-23295. [CrossRef]

61. Tu-Sekine, B.; Raben, D.M. Dual regulation of diacylglycerol kinase (DGK)-theta: Polybasic proteins promote activation by phospholipids and increase substrate affinity. J. Biol. Chem. 2012, 287, 41619-41627. [CrossRef] [PubMed]

62. Houssa, B.; de Widt, J.; Kranenburg, O.; Moolenaar, W.H.; van Blitterswijk, W.J. Diacylglycerol kinase theta binds to and is negatively regulated by active RhoA. J. Biol. Chem. 1999, 274, 6820-6822. [CrossRef] [PubMed]

63. Tu-Sekine, B.; Ostroski, M.; Raben, D.M. Modulation of diacylglycerol kinase theta activity by alpha-thrombin and phospholipids. Biochemistry 2007, 46, 924-932. [CrossRef] [PubMed]

64. Imai, S.; Sakane, F.; Kanoh, H. Phorbol ester-regulated oligomerization of diacylglycerol kinase delta linked to its phosphorylation and translocation. J. Biol. Chem. 2002, 277, 35323-35332. [CrossRef]

65. Imai, S.; Kai, M.; Yamada, K.; Kanoh, H.; Sakane, F. The plasma membrane translocation of diacylglycerol kinase delta1 is negatively regulated by conventional protein kinase C-dependent phosphorylation at Ser-22 and Ser-26 within the pleckstrin homology domain. Biochem. J. 2004, 382, 957-966. [CrossRef]

66. Harada, B.T.; Knight, M.J.; Imai, S.; Qiao, F.; Ramachander, R.; Sawaya, M.R.; Gingery, M.; Sakane, F.; Bowie, J.U. Regulation of enzyme localization by polymerization: Polymer formation by the SAM domain of diacylglycerol kinase delta1. Structure 2008, 16, 380-387. [CrossRef]

67. Shirai, Y.; Segawa, S.; Kuriyama, M.; Goto, K.; Sakai, N.; Saito, N. Subtype-specific translocation of diacylglycerol kinase alpha and gamma and its correlation with protein kinase C. J. Biol. Chem. 2000, 275, 24760-24766. [CrossRef]

68. Yamaguchi, Y.; Shirai, Y.; Matsubara, T.; Sanse, K.; Kuriyama, M.; Oshiro, N.; Yoshino, K.; Yonezawa, K.; Ono, Y.; Saito, N. Phosphorylation and up-regulation of diacylglycerol kinase gamma via its interaction with protein kinase C gamma. J. Biol. Chem. 2006, 281, 31627-31637. [CrossRef]

69. Sanjuan, M.A.; Pradet-Balade, B.; Jones, D.R.; Martinez, A.C.; Stone, J.C.; Garcia-Sanz, J.A.; Merida, I. T cell activation in vivo targets diacylglycerol kinase alpha to the membrane: A novel mechanism for Ras attenuation. J. Immunol. 2003, 170, 2877-2883. [CrossRef]

70. Baldanzi, G.; Cutrupi, S.; Chianale, F.; Gnocchi, V.; Rainero, E.; Porporato, P.; Filigheddu, N.; van Blitterswijk, W.J.; Parolini, O.; Bussolino, F.; et al. Diacylglycerol kinase-alpha phosphorylation by Src on Y335 is required for activation, membrane recruitment and Hgf-induced cell motility. Oncogene 2008, 27, 942-956. [CrossRef]

71. Matsubara, T.; Ikeda, M.; Kiso, Y.; Sakuma, M.; Yoshino, K.; Sakane, F.; Merida, I.; Saito, N.; Shirai, Y. c-Abl tyrosine kinase regulates serum-induced nuclear export of diacylglycerol kinase alpha by phosphorylation at Tyr-218. J. Biol. Chem. 2012, 287, 5507-5517. [CrossRef] [PubMed]

72. Fukunaga-Takenaka, R.; Shirai, Y.; Yagi, K.; Adachi, N.; Sakai, N.; Merino, E.; Merida, I.; Saito, N. Importance of chroman ring and tyrosine phosphorylation in the subtype-specific translocation and activation of diacylglycerol kinase alpha by D-alpha-tocopherol. Genes Cells 2005, 10, 311-319. [CrossRef] [PubMed] 
73. Hayashi, D.; Yagi, K.; Song, C.; Ueda, S.; Yamanoue, M.; Topham, M.; Suzaki, T.; Saito, N.; Emoto, N.; Shirai, Y. Diacylglycerol Kinase alpha is Involved in the Vitamin E-Induced Amelioration of Diabetic Nephropathy in Mice. Sci Rep. 2017, 7, 2597. [CrossRef] [PubMed]

74. Poli, A.; Fiume, R.; Baldanzi, G.; Capello, D.; Ratti, S.; Gesi, M.; Manzoli, L.; Graziani, A.; Suh, P.G.; Cocco, L.; et al. Nuclear Localization of Diacylglycerol Kinase Alpha in K562 Cells Is Involved in Cell Cycle Progression. J. Cell. Physiol. 2017, 232, 2550-2557. [CrossRef] [PubMed]

75. Torres-Ayuso, P.; Daza-Martin, M.; Martin-Perez, J.; Avila-Flores, A.; Merida, I. Diacylglycerol kinase alpha promotes 3D cancer cell growth and limits drug sensitivity through functional interaction with Src. Oncotarget 2014, 5, 9710-9726. [CrossRef]

76. Wada, I.; Kai, M.; Imai, S.; Sakane, F.; Kanoh, H. Translocation of diacylglycerol kinase alpha to the nuclear matrix of rat thymocytes and peripheral T-lymphocytes. FEBS Lett. 1996, 393, 48-52. [CrossRef]

77. Matsubara, T.; Shirai, Y.; Miyasaka, K.; Murakami, T.; Yamaguchi, Y.; Ueyama, T.; Kai, M.; Sakane, F.; Kanoh, H.; Hashimoto, T.; et al. Nuclear transportation of diacylglycerol kinase gamma and its possible function in the nucleus. J. Biol. Chem. 2006, 281, 6152-6164. [CrossRef]

78. Topham, M.K.; Bunting, M.; Zimmerman, G.A.; McIntyre, T.M.; Blackshear, P.J.; Prescott, S.M. Protein kinase $\mathrm{C}$ regulates the nuclear localization of diacylglycerol kinase-zeta. Nature 1998, 394, 697-700. [CrossRef]

79. Ito, T.; Hozumi, Y.; Sakane, F.; Saino-Saito, S.; Kanoh, H.; Aoyagi, M.; Kondo, H.; Goto, K. Cloning and characterization of diacylglycerol kinase iota splice variants in rat brain. J. Biol. Chem. 2004, 279, 23317-23326. [CrossRef]

80. Goto, K.; Watanabe, M.; Kondo, H.; Yuasa, H.; Sakane, F.; Kanoh, H. Gene cloning, sequence, expression and in situ localization of $80 \mathrm{kDa}$ diacylglycerol kinase specific to oligodendrocyte of rat brain. Brain Res. Mol. Brain Res. 1992, 16, 75-87. [CrossRef]

81. Hozumi, Y.; Fukaya, M.; Adachi, N.; Saito, N.; Otani, K.; Kondo, H.; Watanabe, M.; Goto, K. Diacylglycerol kinase beta accumulates on the perisynaptic site of medium spiny neurons in the striatum. Eur. J. Neurosci. 2008, 28, 2409-2422. [CrossRef] [PubMed]

82. Sakai, H.; Sakane, F. Recent progress on type II diacylglycerol kinases: The physiological functions of diacylglycerol kinase delta, eta and kappa and their involvement in disease. J. Biochem. 2012, 152, 397-406. [CrossRef] [PubMed]

83. Shionoya, T.; Usuki, T.; Komenoi, S.; Isozaki, T.; Sakai, H.; Sakane, F. Distinct expression and localization of the type II diacylglycerol kinase isozymes delta, eta and kappa in the mouse reproductive organs. BMC Dev. Biol. 2015, 15. [CrossRef] [PubMed]

84. Manneras-Holm, L.; Kirchner, H.; Bjornholm, M.; Chibalin, A.V.; Zierath, J.R. mRNA expression of diacylglycerol kinase isoforms in insulin-sensitive tissues: Effects of obesity and insulin resistance. Physiol. Rep. 2015, 3. [CrossRef]

85. Sakane, F.; Imai, S.; Yamada, K.; Murakami, T.; Tsushima, S.; Kanoh, H. Alternative splicing of the human diacylglycerol kinase delta gene generates two isoforms differing in their expression patterns and in regulatory functions. J. Biol. Chem. 2002, 277, 43519-43526. [CrossRef]

86. Nagaya, H.; Wada, I.; Jia, Y.J.; Kanoh, H. Diacylglycerol kinase delta suppresses ER-to-Golgi traffic via its SAM and PH domains. Mol. Biol. Cell 2002, 13, 302-316. [CrossRef]

87. Murakami, T.; Sakane, F.; Imai, S.; Houkin, K.; Kanoh, H. Identification and characterization of two splice variants of human diacylglycerol kinase eta. J. Biol. Chem. 2003, 278, 34364-34372. [CrossRef]

88. Rodriguez de Turco, E.B.; Tang, W.; Topham, M.K.; Sakane, F.; Marcheselli, V.L.; Chen, C.; Taketomi, A.; Prescott, S.M.; Bazan, N.G. Diacylglycerol kinase epsilon regulates seizure susceptibility and long-term potentiation through arachidonoyl-inositol lipid signaling. Proc. Natl. Acad. Sci. USA 2001, 98, 4740-4745. [CrossRef]

89. Matsui, H.; Hozumi, Y.; Tanaka, T.; Okada, M.; Nakano, T.; Suzuki, Y.; Iseki, K.; Kakehata, S.; Topham, M.K.; Goto, K. Role of the N-terminal hydrophobic residues of DGKepsilon in targeting the endoplasmic reticulum. Biochim. Biophys. Acta 2014, 1842, 1440-1450. [CrossRef]

90. Saino-Saito, S.; Hozumi, Y.; Goto, K. Excitotoxicity by kainate-induced seizure causes diacylglycerol kinase zeta to shuttle from the nucleus to the cytoplasm in hippocampal neurons. Neurosci. Lett. 2011, 494, 185-189. [CrossRef]

91. Hozumi, Y.; Ito, T.; Nakano, T.; Nakagawa, T.; Aoyagi, M.; Kondo, H.; Goto, K. Nuclear localization of diacylglycerol kinase zeta in neurons. Eur. J. Neurosci. 2003, 18, 1448-1457. [CrossRef] [PubMed] 
92. Hozumi, Y.; Matsui, H.; Sakane, F.; Watanabe, M.; Goto, K. Distinct expression and localization of diacylglycerol kinase isozymes in rat retina. J. Histochem. Cytochem. 2013, 61, 462-476. [CrossRef] [PubMed]

93. Walker, A.J.; Draeger, A.; Houssa, B.; van Blitterswijk, W.J.; Ohanian, V.; Ohanian, J. Diacylglycerol kinase theta is translocated and phosphoinositide 3-kinase-dependently activated by noradrenaline but not angiotensin II in intact small arteries. Biochem. J. 2001, 353, 129-137. [CrossRef] [PubMed]

94. Joshi, R.P.; Koretzky, G.A. Diacylglycerol kinases: Regulated controllers of T cell activation, function, and development. Int. J. Mol. Sci. 2013, 14, 6649-6673. [CrossRef]

95. Zheng, Y.; Zha, Y.; Driessens, G.; Locke, F.; Gajewski, T.F. Transcriptional regulator early growth response gene 2 (Egr2) is required for T cell anergy in vitro and in vivo. J. Exp. Med. 2012, 209, 2157-2163. [CrossRef]

96. Zha, Y.; Marks, R.; Ho, A.W.; Peterson, A.C.; Janardhan, S.; Brown, I.; Praveen, K.; Stang, S.; Stone, J.C.; Gajewski, T.F. T cell anergy is reversed by active Ras and is regulated by diacylglycerol kinase-alpha. Nat. Immunol. 2006, 7, 1166-1173. [CrossRef]

97. Zheng, Y.; Zha, Y.; Spaapen, R.M.; Mathew, R.; Barr, K.; Bendelac, A.; Gajewski, T.F. Egr2-dependent gene expression profiling and ChIP-Seq reveal novel biologic targets in T cell anergy. Mol. Immunol. 2013, 55, $283-291$. [CrossRef]

98. Luo, B.; Prescott, S.M.; Topham, M.K. Association of diacylglycerol kinase zeta with protein kinase C alpha: Spatial regulation of diacylglycerol signaling. J. Cell Biol. 2003, 160, 929-937. [CrossRef]

99. Clarke, C.J.; Ohanian, V.; Ohanian, J. Norepinephrine and endothelin activate diacylglycerol kinases in caveolae/rafts of rat mesenteric arteries: Agonist-specific role of PI3-kinase. Am. J. Physiol. Heart Circ. Physiol. 2007, 292, H2248-H2256. [CrossRef]

100. Cai, K.; Sewer, M.B. cAMP-stimulated transcription of DGKtheta requires steroidogenic factor 1 and sterol regulatory element binding protein 1. J. Lipid Res. 2013, 54, 2121-2132. [CrossRef]

101. Boroda, S.; Niccum, M.; Raje, V.; Purow, B.W.; Harris, T.E. Dual activities of ritanserin and R59022 as DGKalpha inhibitors and serotonin receptor antagonists. Biochem. Pharmacol. 2017, 123, 29-39. [CrossRef] [PubMed]

102. Sato, M.; Liu, K.; Sasaki, S.; Kunii, N.; Sakai, H.; Mizuno, H.; Saga, H.; Sakane, F. Evaluations of the selectivities of the diacylglycerol kinase inhibitors R59022 and R59949 among diacylglycerol kinase isozymes using a new non-radioactive assay method. Pharmacology 2013, 92, 99-107. [CrossRef] [PubMed]

103. Liu, K.; Kunii, N.; Sakuma, M.; Yamaki, A.; Mizuno, S.; Sato, M.; Sakai, H.; Kado, S.; Kumagai, K.; Kojima, H.; et al. A novel diacylglycerol kinase alpha-selective inhibitor, CU-3, induces cancer cell apoptosis and enhances immune response. J. Lipid Res. 2016, 57, 368-379. [CrossRef]

104. Suire, S.; Lecureuil, C.; Anderson, K.E.; Damoulakis, G.; Niewczas, I.; Davidson, K.; Guillou, H.; Pan, D.; Jonathan, C.; Phillip, T.H.; et al. GPCR activation of Ras and PI3Kc in neutrophils depends on PLCb2/b3 and the RasGEF RasGRP4. EMBO J. 2012, 31, 3118-3129. [CrossRef] [PubMed]

105. Velnati, S.; Ruffo, E.; Massarotti, A.; Talmon, M.; Varma, K.S.S.; Gesu, A.; Fresu, L.G.; Snow, A.L.; Bertoni, A.; Capello, D.; et al. Identification of a novel DGKalpha inhibitor for XLP-1 therapy by virtual screening. Eur. J. Med. Chem. 2019, 164, 378-390. [CrossRef]

106. Franks, C.E.; Campbell, S.T.; Purow, B.W.; Harris, T.E.; Hsu, K.L. The Ligand Binding Landscape of Diacylglycerol Kinases. Cell Chem. Biol. 2017, 24, 870-880. [CrossRef]

107. Takahashi, D.; Suzuki, K.; Sakamoto, T.; Iwamoto, T.; Murata, T.; Sakane, F. Crystal structure and calcium-induced conformational changes of diacylglycerol kinase alpha EF-hand domains. Protein Sci. A Publ. Protein Soc. 2019, 28, 694-706. [CrossRef]

108. Zhong, X.P.; Hainey, E.A.; Olenchock, B.A.; Jordan, M.S.; Maltzman, J.S.; Nichols, K.E.; Shen, H.; Koretzky, G.A. Enhanced T cell responses due to diacylglycerol kinase zeta deficiency. Nat. Immunol. 2003, 4, 882-890. [CrossRef]

109. Guo, R.; Wan, C.K.; Carpenter, J.H.; Mousallem, T.; Boustany, R.M.; Kuan, C.T.; Burks, A.W.; Zhong, X.P. Synergistic control of T cell development and tumor suppression by diacylglycerol kinase alpha and zeta. Proc. Natl. Acad. Sci. USA 2008, 105, 11909-11914. [CrossRef]

110. Yang, E.; Singh, B.K.; Paustian, A.M.; Kambayashi, T. Diacylglycerol Kinase zeta Is a Target To Enhance NK Cell Function. J. Immunol. 2016, 197, 934-941. [CrossRef]

111. Macian, F.; Garcia-Cozar, F.; Im, S.H.; Horton, H.F.; Byrne, M.C.; Rao, A. Transcriptional mechanisms underlying lymphocyte tolerance. Cell 2002, 109, 719-731. [CrossRef]

112. Merida, I.; Andrada, E.; Gharbi, S.I.; Avila-Flores, A. Redundant and specialized roles for diacylglycerol kinases alpha and zeta in the control of T cell functions. Sci. Signal. 2015, 8, re6. [CrossRef] [PubMed] 
113. Martinez-Moreno, M.; Garcia-Lievana, J.; Soutar, D.; Torres-Ayuso, P.; Andrada, E.; Zhong, X.P.; Koretzky, G.A.; Merida, I.; Avila-Flores, A. FoxO-dependent regulation of diacylglycerol kinase alpha gene expression. Mol. Cell. Biol. 2012, 32, 4168-4180. [CrossRef] [PubMed]

114. Quann, E.J.; Merino, E.; Furuta, T.; Huse, M. Localized diacylglycerol drives the polarization of the microtubule-organizing center in T cells. Nat. Immunol. 2009, 10, 627-635. [CrossRef]

115. Takeishi, K.; Taketomi, A.; Shirabe, K.; Toshima, T.; Motomura, T.; Ikegami, T.; Yoshizumi, T.; Sakane, F.; Maehara, Y. Diacylglycerol kinase alpha enhances hepatocellular carcinoma progression by activation of Ras-Raf-MEK-ERK pathway. J. Hepatol. 2012, 57, 77-83. [CrossRef]

116. Yasuda, S.; Kai, M.; Imai, S.; Takeishi, K.; Taketomi, A.; Toyota, M.; Kanoh, H.; Sakane, F. Diacylglycerol kinase eta augments C-Raf activity and B-Raf/C-Raf heterodimerization. J. Biol. Chem. 2009, 284, 29559-29570. [CrossRef]

117. Crotty, T.; Cai, J.; Sakane, F.; Taketomi, A.; Prescott, S.M.; Topham, M.K. Diacylglycerol kinase delta regulates protein kinase C and epidermal growth factor receptor signaling. Proc. Natl. Acad. Sci. USA 2006, 103, 15485-15490. [CrossRef]

118. Cai, J.; Crotty, T.M.; Reichert, E.; Carraway, K.L., 3rd; Stafforini, D.M.; Topham, M.K. Diacylglycerol kinase delta and protein kinase $\mathrm{C}$ (alpha) modulate epidermal growth factor receptor abundance and degradation through ubiquitin-specific protease 8. J. Biol. Chem. 2010, 285, 6952-6959. [CrossRef]

119. Regier, D.S.; Higbee, J.; Lund, K.M.; Sakane, F.; Prescott, S.M.; Topham, M.K. Diacylglycerol kinase iota regulates Ras guanyl-releasing protein 3 and inhibits Rap1 signaling. Proc. Natl. Acad. Sci. USA 2005, 102, 7595-7600. [CrossRef]

120. Tsushima, S.; Kai, M.; Yamada, K.; Imai, S.; Houkin, K.; Kanoh, H.; Sakane, F. Diacylglycerol kinase gamma serves as an upstream suppressor of Rac1 and lamellipodium formation. J. Biol. Chem. 2004, 279, 28603-28613. [CrossRef]

121. Kim, J. Regulation of Immune Cell Functions by Metabolic Reprogramming. J. Immunol. Res. 2018, $2018,8605471$. [CrossRef] [PubMed]

122. Noessner, E. DGK-alpha: A Checkpoint in Cancer-Mediated Immuno-Inhibition and Target for Immunotherapy. Front. Cell Dev. Biol. 2017, 5, 16. [CrossRef] [PubMed]

123. Prinz, P.U.; Mendler, A.N.; Masouris, I.; Durner, L.; Oberneder, R.; Noessner, E. High DGK-alpha and disabled MAPK pathways cause dysfunction of human tumor-infiltrating CD8+ T cells that is reversible by pharmacologic intervention. J. Immunol. 2012, 188, 5990-6000. [CrossRef]

124. Singh, B.K.; Kambayashi, T. The Immunomodulatory Functions of Diacylglycerol Kinase zeta. Front. Cell Dev. Biol. 2016, 4, 96. [CrossRef] [PubMed]

125. Tanaka, T.; Okada, M.; Hozumi, Y.; Tachibana, K.; Kitanaka, C.; Hamamoto, Y.; Martelli, A.M.; Topham, M.K.; Iino, M.; Goto, K. Cytoplasmic localization of DGKzeta exerts a protective effect against p53-mediated cytotoxicity. J. Cell Sci. 2013, 126, 2785-2797. [CrossRef]

126. Tsuchiya, R.; Tanaka, T.; Hozumi, Y.; Nakano, T.; Okada, M.; Topham, M.K.; Iino, M.; Goto, K. Downregulation of diacylglycerol kinase zeta enhances activation of cytokine-induced NF-kappaB signaling pathway. Biochim. Biophys. Acta 2015, 1853, 361-369. [CrossRef]

127. Tanaka, T.; Tsuchiya, R.; Hozumi, Y.; Nakano, T.; Okada, M.; Goto, K. Reciprocal regulation of p53 and NF-kappaB by diacylglycerol kinase zeta. Adv. Biol. Regul. 2016, 60, 15-21. [CrossRef]

128. Sano, H.; Kane, S.; Sano, E.; Miinea, C.P.; Asara, J.M.; Lane, W.S.; Garner, C.W.; Lienhard, G.E. Insulin-stimulated phosphorylation of a Rab GTPase-activating protein regulates GLUT4 translocation. J. Biol. Chem. 2003, 278, 14599-14602. [CrossRef]

129. Nagle, C.A.; An, J.; Shiota, M.; Torres, T.P.; Cline, G.W.; Liu, Z.X.; Wang, S.; Catlin, R.L.; Shulman, G.I.; Newgard, C.B.; et al. Hepatic overexpression of glycerol-sn-3-phosphate acyltransferase 1 in rats causes insulin resistance. J. Biol. Chem. 2007, 282, 14807-14815. [CrossRef]

130. Turinsky, J.; O'Sullivan, D.M.; Bayly, B.P. 1,2-Diacylglycerol and ceramide levels in insulin-resistant tissues of the rat in vivo. J. Biol. Chem. 1990, 265, 16880-16885.

131. Monetti, M.; Levin, M.C.; Watt, M.J.; Sajan, M.P.; Marmor, S.; Hubbard, B.K.; Stevens, R.D.; Bain, J.R.; Newgard, C.B.; Farese, R.V., Sr.; et al. Dissociation of hepatic steatosis and insulin resistance in mice overexpressing DGAT in the liver. Cell Metab. 2007, 6, 69-78. [CrossRef] [PubMed]

132. Kumashiro, N.; Erion, D.M.; Zhang, D.; Kahn, M.; Beddow, S.A.; Chu, X.; Still, C.D.; Gerhard, G.S.; Han, X.; Dziura, J.; et al. Cellular mechanism of insulin resistance in nonalcoholic fatty liver disease. Proc. Natl. Acad. Sci. USA 2011, 108, 16381-16385. [CrossRef] [PubMed] 
133. Albert, J.S.; Yerges-Armstrong, L.M.; Horenstein, R.B.; Pollin, T.I.; Sreenivasan, U.T.; Chai, S.; Blaner, W.S.; Snitker, S.; O'Connell, J.R.; Gong, D.W.; et al. Null mutation in hormone-sensitive lipase gene and risk of type 2 diabetes. N. Engl. J. Med. 2014, 370, 2307-2315. [CrossRef] [PubMed]

134. Ahmadian, M.; Duncan, R.E.; Varady, K.A.; Frasson, D.; Hellerstein, M.K.; Birkenfeld, A.L.; Samuel, V.T.; Shulman, G.I.; Wang, Y.; Kang, C.; et al. Adipose overexpression of desnutrin promotes fatty acid use and attenuates diet-induced obesity. Diabetes 2009, 58, 855-866. [CrossRef] [PubMed]

135. Miele, C.; Paturzo, F.; Teperino, R.; Sakane, F.; Fiory, F.; Oriente, F.; Ungaro, P.; Valentino, R.; Beguinot, F.; Formisano, P. Glucose regulates diacylglycerol intracellular levels and protein kinase $C$ activity by modulating diacylglycerol kinase subcellular localization. J. Biol. Chem. 2007, 282, 31835-31843. [CrossRef]

136. Litosch, I. Decoding Galphaq signaling. Life Sci 2016, 152, 99-106. [CrossRef]

137. Litosch, I. Negative feedback regulation of Gq signaling by protein kinase $C$ is disrupted by diacylglycerol kinase zeta in COS-7 cells. Biochem. Biophys. Res. Commun. 2012, 417, 956-960. [CrossRef]

138. Temes, E.; Martin-Puig, S.; Aragones, J.; Jones, D.R.; Olmos, G.; Merida, I.; Landazuri, M.O. Role of diacylglycerol induced by hypoxia in the regulation of HIF-1alpha activity. Biochem. Biophys. Res. Commun. 2004, 315, 44-50. [CrossRef]

139. Temes, E.; Martin-Puig, S.; Acosta-Iborra, B.; Castellanos, M.C.; Feijoo-Cuaresma, M.; Olmos, G.; Aragones, J.; Landazuri, M.O. Activation of HIF-prolyl hydroxylases by R59949, an inhibitor of the diacylglycerol kinase. J. Biol. Chem. 2005, 280, 24238-24244. [CrossRef]

140. Baldanzi, G.; Mitola, S.; Cutrupi, S.; Filigheddu, N.; van Blitterswijk, W.J.; Sinigaglia, F.; Bussolino, F.; Graziani, A. Activation of diacylglycerol kinase alpha is required for VEGF-induced angiogenic signaling in vitro. Oncogene 2004, 23, 4828-4838. [CrossRef]

141. Shimomura, T.; Nakano, T.; Goto, K.; Wakabayashi, I. R59949, a diacylglycerol kinase inhibitor, inhibits inducible nitric oxide production through decreasing transplasmalemmal L-arginine uptake in vascular smooth muscle cells. Naunyn-Schmiedeberg's Arch. Pharmacol. 2017, 390, 207-214. [CrossRef] [PubMed]

142. Yang, L.; Xu, Y.; Li, W.; Yang, B.; Yu, S.; Zhou, H.; Yang, C.; Xu, F.; Wang, J.; Gao, Y.; et al. Diacylglycerol kinase (DGK) inhibitor II (R59949) could suppress retinal neovascularization and protect retinal astrocytes in an oxygen-induced retinopathy model. J. Mol. Neurosci. 2015, 56, 78-88. [CrossRef] [PubMed]

143. Mahmoodnia, L.; Aghadavod, E.; Beigrezaei, S.; Rafieian-Kopaei, M. An update on diabetic kidney disease, oxidative stress and antioxidant agents. J. Renal Inj. Prev. 2017, 6, 153-157. [CrossRef] [PubMed]

144. Xie, S.; Naslavsky, N.; Caplan, S. Diacylglycerol kinases in membrane trafficking. Cell. Logist. 2015, 5, e1078431. [CrossRef]

145. Alonso, R.; Mazzeo, C.; Rodriguez, M.C.; Marsh, M.; Fraile-Ramos, A.; Calvo, V.; Avila-Flores, A.; Merida, I.; Izquierdo, M. Diacylglycerol kinase alpha regulates the formation and polarisation of mature multivesicular bodies involved in the secretion of Fas ligand-containing exosomes in T lymphocytes. Cell Death Differ. 2011, 18, 1161-1173. [CrossRef]

146. Xie, S.; Naslavsky, N.; Caplan, S. Diacylglycerol kinase alpha regulates tubular recycling endosome biogenesis and major histocompatibility complex class I recycling. J. Biol. Chem. 2014, 289, 31914-31926. [CrossRef]

147. Rainero, E.; Caswell, P.T.; Muller, P.A.; Grindlay, J.; McCaffrey, M.W.; Zhang, Q.; Wakelam, M.J.; Vousden, K.H.; Graziani, A.; Norman, J.C. Diacylglycerol kinase alpha controls RCP-dependent integrin trafficking to promote invasive migration. J. Cell Biol. 2012, 196, 277-295. [CrossRef]

148. Alonso, R.; Rodriguez, M.C.; Pindado, J.; Merino, E.; Merida, I.; Izquierdo, M. Diacylglycerol kinase alpha regulates the secretion of lethal exosomes bearing Fas ligand during activation-induced cell death of $\mathrm{T}$ lymphocytes. J. Biol. Chem. 2005, 280, 28439-28450. [CrossRef]

149. Diaz Anel, A.M.; Malhotra, V. PKCeta is required for beta1gamma2/beta3gamma2- and PKD-mediated transport to the cell surface and the organization of the Golgi apparatus. J. Cell Biol. 2005, 169, 83-91. [CrossRef]

150. Wang, Q.J. PKD at the crossroads of DAG and PKC signaling. Trends Pharm. Sci. 2006, 27, 317-323. [CrossRef]

151. Lopez, C.I.; Pelletan, L.E.; Suhaiman, L.; De Blas, G.A.; Vitale, N.; Mayorga, L.S.; Belmonte, S.A. Diacylglycerol stimulates acrosomal exocytosis by feeding into a PKC- and PLD1-dependent positive loop that continuously supplies phosphatidylinositol 4,5-bisphosphate. Biochim. Biophys. Acta 2012, 1821, 1186-1199. [CrossRef] [PubMed]

152. Huang, C.C.; Yang, D.M.; Lin, C.C.; Kao, L.S. Involvement of Rab3A in vesicle priming during exocytosis: Interaction with Munc13-1 and Munc18-1. Traffic 2011, 12, 1356-1370. [CrossRef] [PubMed] 
153. Shemesh, T.; Luini, A.; Malhotra, V.; Burger, K.N.; Kozlov, M.M. Prefission constriction of Golgi tubular carriers driven by local lipid metabolism: A theoretical model. Biophys. J. 2003, 85, 3813-3827. [CrossRef]

154. Carrasco, S.; Merida, I. Diacylglycerol, when simplicity becomes complex. Trends Biochem. Sci. 2007, 32, 27-36. [CrossRef] [PubMed]

155. Merida, I.; Arranz-Nicolas, J.; Rodriguez-Rodriguez, C.; Avila-Flores, A. Diacylglycerol kinase control of protein kinase C. Biochem. J. 2019, 476, 1205-1219. [CrossRef]

156. Okada, M.; Hozumi, Y.; Iwazaki, K.; Misaki, K.; Yanagida, M.; Araki, Y.; Watanabe, T.; Yagisawa, H.; Topham, M.K.; Kaibuchi, K.; et al. DGKzeta is involved in LPS-activated phagocytosis through IQGAP1/Rac1 pathway. Biochem. Biophys. Res. Commun. 2012, 420,479-484. [CrossRef]

157. You, J.S.; Lincoln, H.C.; Kim, C.R.; Frey, J.W.; Goodman, C.A.; Zhong, X.P.; Hornberger, T.A. The role of diacylglycerol kinase zeta and phosphatidic acid in the mechanical activation of mammalian target of rapamycin (mTOR) signaling and skeletal muscle hypertrophy. J. Biol. Chem. 2014, 289, 1551-1563. [CrossRef]

158. Winter, J.N.; Fox, T.E.; Kester, M.; Jefferson, L.S.; Kimball, S.R. Phosphatidic acid mediates activation of mTORC1 through the ERK signaling pathway. Am. J. Physiol. Cell Physiol. 2010, 299, C335-C344. [CrossRef]

159. Yoon, M.S.; Sun, Y.; Arauz, E.; Jiang, Y.; Chen, J. Phosphatidic acid activates mammalian target of rapamycin complex 1 (mTORC1) kinase by displacing FK506 binding protein 38 (FKBP38) and exerting an allosteric effect. J. Biol. Chem. 2011, 286, 29568-29574. [CrossRef]

160. Gorentla, B.K.; Wan, C.K.; Zhong, X.P. Negative regulation of mTOR activation by diacylglycerol kinases. Blood 2011, 117, 4022-4031. [CrossRef]

161. Pettitt, T.R.; McDermott, M.; Saqib, K.M.; Shimwell, N.; Wakelam, M.J. Phospholipase D1b and D2a generate structurally identical phosphatidic acid species in mammalian cells. Biochem. J. 2001, 360, 707-715. [CrossRef] [PubMed]

162. Williams, J.M.; Pettitt, T.R.; Powell, W.; Grove, J.; Savage, C.O.; Wakelam, M.J. Antineutrophil cytoplasm antibody-stimulated neutrophil adhesion depends on diacylglycerol kinase-catalyzed phosphatidic acid formation. J. Am. Soc. Nephrol. 2007, 18, 1112-1120. [CrossRef] [PubMed]

163. Holden, N.J.; Savage, C.O.; Young, S.P.; Wakelam, M.J.; Harper, L.; Williams, J.M. A dual role for diacylglycerol kinase generated phosphatidic acid in autoantibody-induced neutrophil exocytosis. Mol. Med. 2011, 17, 1242-1252. [CrossRef] [PubMed]

164. Han, H.; Qi, R.; Zhou, J.J.; Ta, A.P.; Yang, B.; Nakaoka, H.J.; Seo, G.; Guan, K.L.; Luo, R.; Wang, W. Regulation of the Hippo Pathway by Phosphatidic Acid-Mediated Lipid-Protein Interaction. Mol. Cell 2018, 72, 328-340. [CrossRef] [PubMed]

165. Gong, R.; Hong, A.W.; Plouffe, S.W.; Zhao, B.; Liu, G.; Yu, F.X.; Xu, Y.; Guan, K.L. Opposing roles of conventional and novel PKC isoforms in Hippo-YAP pathway regulation. Cell Res. 2015, 25, 985-988. [CrossRef]

166. Goto, K.; Nakano, T.; Hozumi, Y. Diacylglycerol kinase and animal models: The pathophysiological roles in the brain and heart. Adv. Enzym. Regul. 2006, 46, 192-202. [CrossRef]

167. Chibalin, A.V.; Leng, Y.; Vieira, E.; Krook, A.; Bjornholm, M.; Long, Y.C.; Kotova, O.; Zhong, Z.; Sakane, F.; Steiler, T.; et al. Downregulation of diacylglycerol kinase delta contributes to hyperglycemia-induced insulin resistance. Cell 2008, 132, 375-386. [CrossRef]

168. Tabet, R.; Moutin, E.; Becker, J.A.; Heintz, D.; Fouillen, L.; Flatter, E.; Krezel, W.; Alunni, V.; Koebel, P.; Dembele, D.; et al. Fragile X Mental Retardation Protein (FMRP) controls diacylglycerol kinase activity in neurons. Proc. Natl. Acad. Sci. USA 2016, 113, E3619-E3628. [CrossRef]

169. Bisio, H.; Lunghi, M.; Brochet, M.; Soldati-Favre, D. Phosphatidic acid governs natural egress in Toxoplasma gondii via a guanylate cyclase receptor platform. Nat. Microbiol. 2019, 4, 420-428. [CrossRef]

170. Van der Zanden, L.F.; van Rooij, I.A.; Feitz, W.F.; Knight, J.; Donders, A.R.; Renkema, K.Y.; Bongers, E.M.; Vermeulen, S.H.; Kiemeney, L.A.; Veltman, J.A.; et al. Common variants in DGKK are strongly associated with risk of hypospadias. Nat. Genet. 2011, 43, 48-50. [CrossRef]

171. Lemaire, M.; Fremeaux-Bacchi, V.; Schaefer, F.; Choi, M.; Tang, W.H.; Le Quintrec, M.; Fakhouri, F.; Taque, S.; Nobili, F.; Martinez, F.; et al. Recessive mutations in DGKE cause atypical hemolytic-uremic syndrome. Nat. Genet. 2013, 45, 531-536. [CrossRef] [PubMed]

172. Zhu, J.; Chaki, M.; Lu, D.; Ren, C.; Wang, S.S.; Rauhauser, A.; Li, B.; Zimmerman, S.; Jun, B.; Du, Y.; et al. Loss of diacylglycerol kinase epsilon in mice causes endothelial distress and impairs glomerular Cox-2 and PGE2 production. Am. J. Physiol. Ren. Physiol. 2016, 310, F895-F908. [CrossRef] [PubMed] 
173. Dominguez, C.L.; Floyd, D.H.; Xiao, A.; Mullins, G.R.; Kefas, B.A.; Xin, W.; Yacur, M.N.; Abounader, R.; Lee, J.K.; Wilson, G.M.; et al. Diacylglycerol kinase alpha is a critical signaling node and novel therapeutic target in glioblastoma and other cancers. Cancer Discov. 2013, 3, 782-797. [CrossRef] [PubMed]

174. Purow, B. Molecular Pathways: Targeting Diacylglycerol Kinase Alpha in Cancer. Clin. Cancer Res. 2015, 21, 5008-5012. [CrossRef] [PubMed]

175. Weigel, C.; Veldwijk, M.R.; Oakes, C.C.; Seibold, P.; Slynko, A.; Liesenfeld, D.B.; Rabionet, M.; Hanke, S.A.; Wenz, F.; Sperk, E.; et al. Epigenetic regulation of diacylglycerol kinase alpha promotes radiation-induced fibrosis. Nat. Commun. 2016, 7, 10893. [CrossRef]

176. McMurray, H.R.; Sampson, E.R.; Compitello, G.; Kinsey, C.; Newman, L.; Smith, B.; Chen, S.R.; Klebanov, L.; Salzman, P.; Yakovlev, A.; et al. Synergistic response to oncogenic mutations defines gene class critical to cancer phenotype. Nature 2008, 453, 1112-1116. [CrossRef]

177. Kong, Y.; Zheng, Y.; Jia, Y.; Li, P.; Wang, Y. Decreased LIPF expression is correlated with DGKA and predicts poor outcome of gastric cancer. Oncol. Rep. 2016, 36, 1852-1860. [CrossRef]

178. Berrar, D.; Sturgeon, B.; Bradbury, I.; Downes, C.S.; Dubitzky, W. Survival trees for analyzing clinical outcome in lung adenocarcinomas based on gene expression profiles: Identification of neogenin and diacylglycerol kinase alpha expression as critical factors. J. Comput. Biol. 2005, 12, 534-544. [CrossRef]

179. Merida, I.; Torres-Ayuso, P.; Avila-Flores, A.; Arranz-Nicolas, J.; Andrada, E.; Tello-Lafoz, M.; Liebana, R.; Arcos, R. Diacylglycerol kinases in cancer. Adv. Biol. Regul. 2017, 63, 22-31. [CrossRef]

180. Yanagisawa, K.; Yasuda, S.; Kai, M.; Imai, S.; Yamada, K.; Yamashita, T.; Jimbow, K.; Kanoh, H.; Sakane, F. Diacylglycerol kinase alpha suppresses tumor necrosis factor-alpha-induced apoptosis of human melanoma cells through NF-kappaB activation. Biochim. Biophys. Acta 2007, 1771, 462-474. [CrossRef]

181. Kai, M.; Yamamoto, E.; Sato, A.; Yamano, H.O.; Niinuma, T.; Kitajima, H.; Harada, T.; Aoki, H.; Maruyama, R.; Toyota, M.; et al. Epigenetic silencing of diacylglycerol kinase gamma in colorectal cancer. Mol. Carcinog. 2017, 56, 1743-1752. [CrossRef] [PubMed]

182. Baldanzi, G.; Pietronave, S.; Locarno, D.; Merlin, S.; Porporato, P.; Chianale, F.; Filigheddu, N.; Cantelmo, A.R.; Albini, A.; Graziani, A.; et al. Diacylglycerol kinases are essential for hepatocyte growth factor-dependent proliferation and motility of Kaposi's sarcoma cells. Cancer Sci. 2011, 102, 1329-1336. [CrossRef] [PubMed]

183. Diao, J.; Wu, C.; Zhang, J.; Liu, J.; Zhang, X.; Hao, P.; Zhao, S.; Zhang, Z. Loss of Diacylglycerol Kinase-Zeta Inhibits Cell Proliferation and Survival in Human Gliomas. Mol. Neurobiol. 2016, 53, 5425-5435. [CrossRef] [PubMed]

184. Cai, K.; Mulatz, K.; Ard, R.; Nguyen, T.; Gee, S.H. Increased diacylglycerol kinase zeta expression in human metastatic colon cancer cells augments Rho GTPase activity and contributes to enhanced invasion. BMC Cancer 2014, 14, 208. [CrossRef]

185. Torres-Ayuso, P.; Tello-Lafoz, M.; Merida, I.; Avila-Flores, A. Diacylglycerol kinase-zeta regulates mTORC1 and lipogenic metabolism in cancer cells through SREBP-1. Oncogenesis 2015, 4, e164. [CrossRef]

186. Park, S.; Kang, H.J.; Jeon, J.H.; Kim, M.J.; Lee, I.K. Recent advances in the pathogenesis of microvascular complications in diabetes. Arch. Pharm. Res. 2019, 42, 252-262. [CrossRef]

187. Yang, D.; Kim, J. Mitochondrial Retrograde Signalling and Metabolic Alterations in the Tumour Microenvironment. Cells 2019, 8, 275. [CrossRef]

188. Nascimento, E.B.M.; Manneras-Holm, L.; Chibalin, A.V.; Bjornholm, M.; Zierath, J.R. Diacylglycerol kinase alpha deficiency alters inflammation markers in adipose tissue in response to a high-fat diet. J. Lipid Res. 2018, 59, 273-282. [CrossRef]

189. Kurohane Kaneko, Y.; Kobayashi, Y.; Motoki, K.; Nakata, K.; Miyagawa, S.; Yamamoto, M.; Hayashi, D.; Shirai, Y.; Sakane, F.; Ishikawa, T. Depression of type I diacylglycerol kinases in pancreatic beta-cells from male mice results in impaired insulin secretion. Endocrinology 2013, 154, 4089-4098. [CrossRef]

190. Manneras-Holm, L.; Schonke, M.; Brozinick, J.T.; Vetterli, L.; Bui, H.H.; Sanders, P.; Nascimento, E.B.M.; Bjornholm, M.; Chibalin, A.V.; Zierath, J.R. Diacylglycerol kinase epsilon deficiency preserves glucose tolerance and modulates lipid metabolism in obese mice. J. Lipid Res. 2017, 58, 907-915. [CrossRef]

191. Benziane, B.; Borg, M.L.; Tom, R.Z.; Riedl, I.; Massart, J.; Bjornholm, M.; Gilbert, M.; Chibalin, A.V.; Zierath, J.R. DGKzeta deficiency protects against peripheral insulin resistance and improves energy metabolism. J. Lipid Res. 2017, 58, 2324-2333. [CrossRef] [PubMed] 
192. Chen, Y.P.; Song, W.; Huang, R.; Chen, K.; Zhao, B.; Li, J.; Yang, Y.; Shang, H.F. GAK rs1564282 and DGKQ rs11248060 increase the risk for Parkinson's disease in a Chinese population. J. Clin. Neurosci. 2013, 20, 880-883. [CrossRef] [PubMed]

193. Bras, J.; Guerreiro, R.; Hardy, J. SnapShot: Genetics of Parkinson's disease. Cell 2015, 160. [CrossRef] [PubMed]

194. Lee, D.; Kim, E.; Tanaka-Yamamoto, K. Diacylglycerol Kinases in the Coordination of Synaptic Plasticity. Front. Cell Dev. Biol. 2016, 4, 92. [CrossRef]

195. Hansell, N.K.; Halford, G.S.; Andrews, G.; Shum, D.H.; Harris, S.E.; Davies, G.; Franic, S.; Christoforou, A.; Zietsch, B.; Painter, J.; et al. Genetic basis of a cognitive complexity metric. PLoS ONE 2015, 10, e0123886. [CrossRef]

196. Shirai, Y.; Kouzuki, T.; Kakefuda, K.; Moriguchi, S.; Oyagi, A.; Horie, K.; Morita, S.Y.; Shimazawa, M.; Fukunaga, K.; Takeda, J.; et al. Essential role of neuron-enriched diacylglycerol kinase (DGK), DGKbeta in neurite spine formation, contributing to cognitive function. PLOS ONE 2010, 5, e11602. [CrossRef]

197. Ishisaka, M.; Hara, H. The roles of diacylglycerol kinases in the central nervous system: Review of genetic studies in mice. J. Pharmacol. Sci. 2014, 124, 336-343. [CrossRef]

198. Kakefuda, K.; Oyagi, A.; Ishisaka, M.; Tsuruma, K.; Shimazawa, M.; Yokota, K.; Shirai, Y.; Horie, K.; Saito, N.; Takeda, J.; et al. Diacylglycerol kinase beta knockout mice exhibit lithium-sensitive behavioral abnormalities. PLOS ONE 2010, 5, e13447. [CrossRef]

199. Usuki, T.; Takato, T.; Lu, Q.; Sakai, H.; Bando, K.; Kiyonari, H.; Sakane, F. Behavioral and pharmacological phenotypes of brain-specific diacylglycerol kinase delta-knockout mice. Brain Res. 2016, 1648, 193-201. [CrossRef]

200. Isozaki, T.; Komenoi, S.; Lu, Q.; Usuki, T.; Tomokata, S.; Matsutomo, D.; Sakai, H.; Bando, K.; Kiyonari, H.; Sakane, F. Deficiency of diacylglycerol kinase eta induces lithium-sensitive mania-like behavior. J. Neurochem. 2016, 138, 448-456. [CrossRef]

201. Zhang, N.; Li, B.; Al-Ramahi, I.; Cong, X.; Held, J.M.; Kim, E.; Botas, J.; Gibson, B.W.; Ellerby, L.M. Inhibition of lipid signaling enzyme diacylglycerol kinase epsilon attenuates mutant huntingtin toxicity. J. Biol. Chem. 2012, 287, 21204-21213. [CrossRef] [PubMed]

202. Kim, K.; Yang, J.; Zhong, X.P.; Kim, M.H.; Kim, Y.S.; Lee, H.W.; Han, S.; Choi, J.; Han, K.; Seo, J.; et al. Synaptic removal of diacylglycerol by DGKzeta and PSD-95 regulates dendritic spine maintenance. EMBO J. 2009, 28, 1170-1179. [CrossRef] [PubMed]

203. Sitaram, P.; Uyemura, B.; Malarkannan, S.; Riese, M.J. Beyond the Cell Surface: Targeting Intracellular Negative Regulators to Enhance T cell Anti-Tumor Activity. Int. J. Mol. Sci. 2019, 20, 5821. [CrossRef] [PubMed]

204. Singh, B.K.; Lu, W.; Schmidt Paustian, A.M.; Ge, M.Q.; Koziol-White, C.J.; Flayer, C.H.; Killingbeck, S.S.; Wang, N.; Dong, X.; Riese, M.J.; et al. Diacylglycerol kinase zeta promotes allergic airway inflammation and airway hyperresponsiveness through distinct mechanisms. Sci Signal. 2019, 12. [CrossRef]

205. Mahajan, S.; Mellins, E.D.; Faccio, R. Diacylglycerol Kinase zeta Regulates Macrophage Responses in Juvenile Arthritis and Cytokine Storm Syndrome Mouse Models. J. Immunol. 2020, 204, 137-146. [CrossRef]

206. Olenchock, B.A.; Guo, R.; Silverman, M.A.; Wu, J.N.; Carpenter, J.H.; Koretzky, G.A.; Zhong, X.P. Impaired degranulation but enhanced cytokine production after Fc epsilonRI stimulation of diacylglycerol kinase zeta-deficient mast cells. J. Exp. Med. 2006, 203, 1471-1480. [CrossRef]

207. Sakuma, M.; Shirai, Y.; Ueyama, T.; Saito, N. Diacylglycerol kinase gamma regulates antigen-induced mast cell degranulation by mediating $\mathrm{Ca}(2+)$ influxes. Biochem. Biophys. Res. Commun. 2014, 445, 340-345. [CrossRef]

208. Gray, R.D.; Lucas, C.D.; MacKellar, A.; Li, F.; Hiersemenzel, K.; Haslett, C.; Davidson, D.J.; Rossi, A.G. Activation of conventional protein kinase $\mathrm{C}(\mathrm{PKC})$ is critical in the generation of human neutrophil extracellular traps. J. Inflamm. 2013, 10, 12. [CrossRef]

209. Baldanzi, G.; Malerba, M. DGKalpha in Neutrophil Biology and Its Implications for Respiratory Diseases. Int. J. Mol. Sci. 2019, 20, 5673. [CrossRef]

210. Muid, R.E.; Penfield, A.; Dale, M.M. The diacylglycerol kinase inhibitor, R59022, enhances the superoxide generation from human neutrophils induced by stimulation of fMet-Leu-Phe, IgG and C3b receptors. Biochem. Biophys. Res. Commun. 1987, 143, 630-637. [CrossRef]

(C) 2020 by the authors. Licensee MDPI, Basel, Switzerland. This article is an open access article distributed under the terms and conditions of the Creative Commons Attribution (CC BY) license (http://creativecommons.org/licenses/by/4.0/). 